\title{
The Relationship among Caregiver Burden, Demographic Variables, and the Clinical Characteristics of Patients with Parkinson's Disease-A Systematic Review of Studies Using Various Caregiver Burden Instruments
}

\author{
Ingrid Leiknes ${ }^{1}{ }^{*}$, Unn-Tone Lien ${ }^{2}$, Elisabeth Severinsson ${ }^{3}$ \\ ${ }^{1}$ Centre for Movement Disorders, Stavanger University Hospital, Stavanger, Norway \\ ${ }^{2}$ Centre for Women's, Family \& Child Health, Faculty of Health Sciences, Buskerud \& Vestfold University College, \\ Kongsberg, Norway \\ ${ }^{3}$ Research Department, Stavanger University Hospital and Centre for Women's, Family \& Child Health, Faculty \\ of Health Sciences, Buskerud \& Vestfold University College, Kongsberg, Norway \\ Email: ${ }^{*}$ leii@sus.no
}

Received 24 August 2015; accepted 13 October 2015; published 16 October 2015

Copyright (C) 2015 by authors and Scientific Research Publishing Inc.

This work is licensed under the Creative Commons Attribution International License (CC BY).

http://creativecommons.org/licenses/by/4.0/

(c) (i) Open Access

\section{Abstract}

Caring for a person with Parkinson's disease (PD) extends far beyond the ordinary exchange of assistance among people in a close relationship. Caregivers must learn to cope with the patient's increasing disability and loss of independence. The aim of this systematic review was to critically assess and summarize the evidence of the influence of the demographic and clinical characteristics of patients with PD on caregiver burden by means of a caregiver burden instrument. In order to identify articles, electronic databases and reference lists were searched using the search word "Parkinson's disease" in combination with "caregiver" or "carer" and with "burden" or "distress" or "stress" or "strain". Thirty one articles were deemed eligible for inclusion. The methodological quality of the studies was evaluated. No studies were excluded due to low quality. The results revealed similar associations among caregiver burden, demographic variables and patient characteristics, across different caregiver burden instruments and various clinical scales. Higher PD stage and functional disability are the non-motor characteristics that contribute the most to caregiver burden. However, when comparing the impact of patient motor and non-motor symptoms,

${ }^{*}$ Corresponding author.

How to cite this paper: Leiknes, I., Lien, U.-T. and Severinsson, E. (2015) The Relationship among Caregiver Burden, Demographic Variables, and the Clinical Characteristics of Patients with Parkinson's Disease-A Systematic Review of Studies Using Various Caregiver Burden Instruments. Open Journal of Nursing, 5, 855-877. http://dx.doi.org/10.4236/ojn.2015.510091 
several studies found that mental symptoms had a stronger impact on caregiver burden than motor symptoms. No association was observed between caregiver burden and patient and caregiver demographics with the exception of the sub-scale analysis of caregiver burden in various age groups. Interpreting the results of studies that employ a range of different clinical assessment scales and burden instruments makes it challenging to provide a valid summary of caregiver burden in PD. The most commonly used analysis methods contribute little information about burden variation across caregiver groups or which areas are the most burdensome for caregivers. There is a need for a more uniform use of recommended instruments and for longitudinal studies.

\title{
Keywords
}

\author{
Caregiver Burden, Distress, Strain, Stress, Parkinson's Disease
}

\section{Introduction}

From birth we depend on other persons' caring to survive. The need to be cared for presupposes the responsibility and capacity of another person to provide care. Accordingly, caregiving can be viewed as a response to the care needs of the other. Although caregiving is embedded in all close relationships, many people experience its transformation from the ordinary exchange of assistance to a situation that calls for a more extensive form of caregiving when a close person is not adequately taken care of by her/himself or by the professional healthcare service. Parkinson's disease (PD) is one such situation. PD is a progressive neurological condition characterized by motor symptoms comprising tremor, rigidity, bradykinesia, postural instability and gait difficulties [1]. In addition, most people with PD will experience some non-motor symptoms including neuropsychiatric problems such as psychosis, depression, anxiety, fatigue, apathy and dementia as well as sleep disturbance and autonomic dysfunction with gastrointestinal, urinary and sexual malfunction [1].

Initially, a person with PD responds well to antiparkinson medication. However, the effect usually wears off after several years and the symptoms become more prominent with increasing motor disability and complications such as involuntary and uncontrollable movements [2] and the fluctuating benefit of the medications [3]. Fluctuations are experienced as a switch between mobility and immobility, called the On-Off phenomenon, which is often followed by additional non-motor fluctuations [4]. In the same way as the person with PD, her/his family and significant others have to cope with these challenges and accommodate themselves to the unpredictable On-Off phenomenon, the increasing disability and need for assistance characteristic of advanced PD. Despite limited evidence in the PD population, increased strain [5] and overwhelming caregiver demands [6] have been reported to trigger caregivers' long term care (LTC) placement decisions. In the UK, LTC facilities for PD patients have been estimated to represent a 4.5 times higher healthcare cost than that of patients who are able to live at home [7]. In a Norwegian study, Vossius et al. [8] found that even a few months delay in admission to a nursing home could reduce these costs considerably. Accordingly, there is a need for knowledge about which factors may undermine informal caregivers' ability to provide support and continue in their caring role.

Strain or load experienced by those caring for a person with a chronic disease is often referred to as caregiver burden [9], distress [10], stress [11] or strain [12]. In the literature these terms are frequently used interchangeably [13], although caregivers' subjective and objective burden related to the emotional, physical and social problems that arise from caring for a person with a chronic and disabling disease are covered by most instruments addressing these constructs [14]. A number of instruments have been designed to assess caregivers' situation [14] [15]. In a review, Durme et al. [14] identified 55 scales (mainly generic) assessing the negative impact of caregiving, of which 42 evaluated burden, strain or stress as the main dimension. The current interest in the impact of caregiving has also resulted in an increasing number of studies focusing on caregiver burden in PD [16]. Furthermore, three reviews related to caregiving outcomes in PD have recently been published (Lau et al. [10], Martinez-Martin et al. [17] and Greenwell et al. [18]). The review by Lau et al. [10] is a meta-analysis of the correlates of caregiver distress. Martinez-Martin et al. [17] reviewed the state of the art regarding concepts, assessments, related factors, costs and intervention programmes on PD caregivers' quality of life (QoL) and burden. The systematic review by Greenwell et al. [18] aimed to evaluate the evidence of the predictive factors of psychosocial outcomes, including burden, mental health and QoL in PD carers. 


\section{Aim and Review Questions}

The aim of this systematic review was to critically assess and summarize the evidence of the influence of the demographic and clinical characteristics of patients with PD on caregiver burden by means of a caregiver burden instrument. Two review questions were addressed:

1) How did the demographic and clinical characteristics of patients with PD influence caregiver burden?

2) What instruments and which analyses were used to assess caregiver burden in relation to PD?

\section{Methods}

This review was guided by recommendations in the Preferred Reporting Items for Systematic Reviews and Meta-Analysis (PRISMA) checklist [19].

\subsection{Search Strategy}

A search of the literature was performed in mid-January 2014 in the Pubmed, Medline, PsychInfo, Cinahl, Web of Science and Embase electronic databases. The search term employed was "Parkinson's disease" in combination with "caregiver" or "carer" and with "burden" or "distress" or "stress" or "strain". The search was limited to English and Scandinavian languages. There were no limitations in terms of publication year. A manual search was also made of the reference lists of the articles included in the review. A total of 581 articles were identified, of which 318 were duplicates.

\subsection{Inclusion and Exclusion Criteria}

All articles were assessed for inclusion based on the following criteria: 1) original empirical study, 2) published in peer-reviewed journals, 3 ) with an identifiable and separately analysed group of informal caregivers of persons diagnosed with PD, 4) explored characteristics that are assumed to influence caregiver burden and 5) burden was measured by means of a standardized caregiver instrument. The sample size of eligible studies was $\geq 50$ caregivers, which has been suggested as a reasonable number of cases to ensure statistical power in correlation and regression analysis [20]. Exclusion criteria were intervention studies, medical trials and testing of instruments. Seventy titles were identified as relevant for inclusion. After reading the abstracts, 23 of the 70 articles were excluded in line with the inclusion and exclusion criteria, while another 16 articles were excluded after reading the full text, leaving a total of 31 studies for inclusion (Table 1). The flow chart illustrating study selection and the reasons for exclusion is presented in Figure 1.

\subsection{Data Extraction}

For data extraction, two authors (IL, UTL) independently identified the characteristics of the studies such as authors, publication year, country of origin, aim, participants, recruitment methods, study design, main definitions, outcome measures, statistical analysis and key findings. The first author (IL) identified and categorized all de-

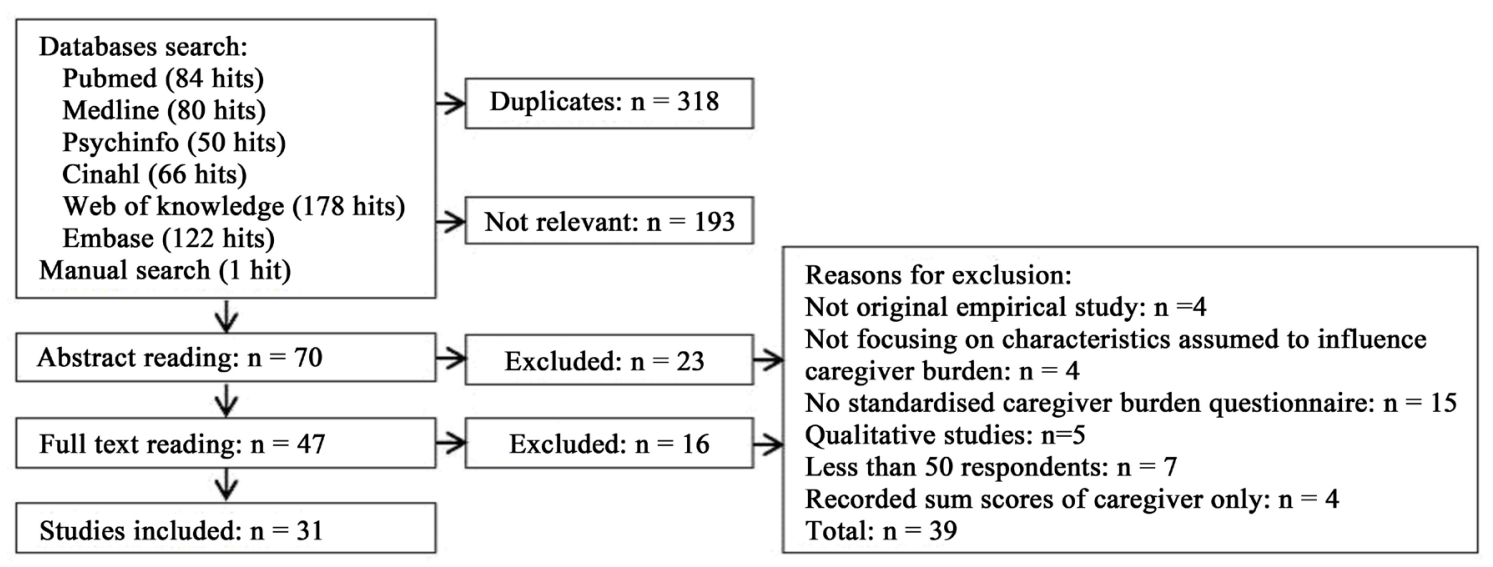

Figure 1. Flow chart of study selection and reasons for exclusion. 
Table 1. Characteristics of the included studies.

\begin{tabular}{|c|c|c|c|c|}
\hline $\begin{array}{l}\text { Authors } \\
\text { (year of publica- } \\
\text { tion) [Reference] } \\
\text { Location }\end{array}$ & $\begin{array}{l}\text { Aim } \\
\text { Definition of caregiver burden }\end{array}$ & $\begin{array}{l}\text { Sample } \\
\text { (relationship) }\end{array}$ & $\begin{array}{l}\text { Statistical analyses } \\
\text { Reported } \\
\text { sub-scores or single } \\
\text { items of the out- } \\
\text { come measures } \\
\text { (Yes/No) }\end{array}$ & $\begin{array}{l}\text { Key findings related to caregiver } \\
\text { burden }\end{array}$ \\
\hline $\begin{array}{l}\text { Kudlicka et al. } \\
\text { (2014) [66] } \\
\text { United Kingdom }\end{array}$ & $\begin{array}{l}\text { To evaluate how executive func- } \\
\text { tions contribute to caregiver bur- } \\
\text { den, as well as QoL and subjective } \\
\text { health status of non-demented and } \\
\text { non-depressed people with } \\
\text { early-stage PD } \\
\text { No definition }\end{array}$ & $\begin{array}{l}50 \text { caregivers } \\
(45 \text { spouses, } \\
3 \text { parents } \\
7 \text { children, } \\
2 \text { friends) }\end{array}$ & $\begin{array}{l}\text { Multiple regression } \\
\text { analysis } \\
\text { No }\end{array}$ & $\begin{array}{l}\text { Caregiver burden was best explained } \\
\text { by caregiver rated executive function } \\
\text { of the PD patient, followed by dis- } \\
\text { ease severity }\end{array}$ \\
\hline $\begin{array}{l}\text { Carod-Artal et al. } \\
(2013)[61] \\
\text { Brazil }\end{array}$ & $\begin{array}{l}\text { To analyse the main determinants } \\
\text { of burden and HRQoL in Brazilian } \\
\text { PD patients } \\
\text { No definition }\end{array}$ & $\begin{array}{l}50 \text { caregivers } \\
(39 \text { spouses, } \\
7 \text { children, } \\
4 \text { others) }\end{array}$ & $\begin{array}{l}\text { Multiple regression } \\
\text { Yes }\end{array}$ & $\begin{array}{l}\text { The patient variables sleep disorders } \\
\text { and behavioural psychotic symptoms } \\
\text { were independent predictors of care- } \\
\text { giver burden }\end{array}$ \\
\hline $\begin{array}{l}\text { Oguh et al. } \\
(2013)[65] \\
\text { USA }\end{array}$ & $\begin{array}{l}\text { To determine what measures of } \\
\text { PD disability, demographics and } \\
\text { patient QoL are associated with } \\
\text { caregiver strain } \\
\text { No definition }\end{array}$ & $\begin{array}{l}2476 \text { caregivers } \\
(91 \% \\
\text { spouses/partners, } \\
9.4 \% \text { other relatives, } \\
0.5 \% \text { other non-paid } \\
\text { caregivers })\end{array}$ & $\begin{array}{l}\text { Multiple logistic } \\
\text { regression } \\
\text { No }\end{array}$ & $\begin{array}{l}\text { Patient quality of life impairment, } \\
\text { male sex, disease severity, presence } \\
\text { of concomitant medications and } \\
\text { decreased verbal fluency were factors } \\
\text { that predicted the likelihood of high } \\
\text { caregiver strain }\end{array}$ \\
\hline $\begin{array}{l}\text { Tanji et al. } \\
(2013)[54] \\
\text { Japan and USA }\end{array}$ & $\begin{array}{l}\text { To compare caregiver strain in } \\
\text { spouses in one region of Japan and } \\
\text { one in the US and examine the } \\
\text { correlation between caregiver } \\
\text { strain and patient/spousal variables } \\
\text { No definition }\end{array}$ & $\begin{array}{l}178 \text { caregivers } \\
\text { (Spouses) }\end{array}$ & $\begin{array}{l}\text { Spearman's rho } \\
t \text {-test } \\
\text { Multivariate re- } \\
\text { gression analysis } \\
\text { Yes }\end{array}$ & $\begin{array}{l}\text { Spouses in the Japanese group re- } \\
\text { ported more physical, time and finan- } \\
\text { cial caregiver strain. The US group } \\
\text { reported more emotional strain. } \\
\text { Falls was the most predictive patient } \\
\text { variable for caregiver strain in the } \\
\text { Japanese group. In the US group, } \\
\text { patient depression was the most pre- } \\
\text { dictive variable for caregiver strain }\end{array}$ \\
\hline $\begin{array}{l}\text { Agrawal et al. } \\
\text { (2012) [35] India }\end{array}$ & $\begin{array}{l}\text { To find various predictors of care- } \\
\text { giver burden in caregivers of per- } \\
\text { sons with PD in India } \\
\text { "The physical, mental and socio- } \\
\text { economic problems experienced } \\
\text { by the caregivers of chronic dis- } \\
\text { ease patients" (p. 59) }\end{array}$ & $\begin{array}{l}91 \text { caregivers } \\
(45 \text { spouses, } \\
32 \text { children, } \\
7 \text { siblings, } \\
7 \text { others) }\end{array}$ & $\begin{array}{l}\text { Linear regression } \\
\text { No }\end{array}$ & $\begin{array}{l}\text { Patient depression scores were the } \\
\text { best predictor of increased caregiver } \\
\text { burden, followed by patient motor } \\
\text { scores and the presence of sleep } \\
\text { disturbances }\end{array}$ \\
\hline $\begin{array}{l}\text { Kelly et al. } \\
(2012)[12] \\
\text { Australia }\end{array}$ & $\begin{array}{l}\text { To consider the relationship be- } \\
\text { tween HRQoL in non-demented } \\
\text { PwPD and their caregivers and to } \\
\text { determine the associations be- } \\
\text { tween caregiver and patient } \\
\text { HRQoL and caregiver strain } \\
\text { "An enduring change ... in care- } \\
\text { giver's fabric of well-being" (p. 2) }\end{array}$ & $\begin{array}{l}97 \text { caregivers } \\
(84 \% \text { spouses, } \\
13 \% \text { children, } \\
3 \% \text { others })\end{array}$ & $\begin{array}{l}\text { Spearman's rho } \\
\text { No }\end{array}$ & $\begin{array}{l}\text { Correlation was found between care- } \\
\text { giver strain and the HRQoL of the } \\
\text { person with PD }\end{array}$ \\
\hline $\begin{array}{l}\text { Leroi et al. } \\
\text { (2012) [49] } \\
\text { United Kingdom }\end{array}$ & $\begin{array}{l}\text { To compare quality of life, level of } \\
\text { disability and caregiver burden } \\
\text { among PwPD with mild cognitive } \\
\text { impairment (PD-MCI), PwPD } \\
\text { with dementia (PDD), and PwPD } \\
\text { with no cognitive impairment } \\
\text { (PD-NC) } \\
\text { No definition }\end{array}$ & $\begin{array}{l}102 \text { caregivers } \\
(55 \text { spouses, } \\
47 \text { adult children) }\end{array}$ & $\begin{array}{l}\text { Analysis of covari- } \\
\text { ance } \\
\text { Analysis of vari- } \\
\text { ance } \\
\text { No }\end{array}$ & $\begin{array}{l}\text { Caregiver burden as assessed by the } \\
\text { ZBI was significantly greater in the } \\
\text { PDD group compared to the two groups } \\
\text { without dementia when adjusted for } \\
\text { age and motor symptom severity. } \\
\text { No significant difference in caregiver } \\
\text { distress was observed between the } \\
\text { three PD caregiver groups assessed } \\
\text { by the NPI-CD }\end{array}$ \\
\hline
\end{tabular}




\section{Continued}

\begin{tabular}{|c|c|c|c|c|}
\hline $\begin{array}{l}\text { Ozdilek and } \\
\text { Gunal (2012) } \\
{[38]} \\
\text { Turkey }\end{array}$ & $\begin{array}{l}\text { To examine the impact of motor } \\
\text { and non-motor symptoms of } \\
\text { non-demented PwPD on the psy- } \\
\text { chological health, burden and QoL } \\
\text { of caregivers }\end{array}$ & $\begin{array}{l}50 \text { caregivers } \\
(37 \text { spouses, } \\
11 \text { children, } \\
2 \text { siblings })\end{array}$ & $\begin{array}{l}\text { Person's correlation } \\
\text { coefficient (multi- } \\
\text { ple linear regres- } \\
\text { sion-results not } \\
\text { given) }\end{array}$ & $\begin{array}{l}\text { Caregiver burden was positively } \\
\text { associated with the patient-related } \\
\text { variables; disease stage, disease se- } \\
\text { verity, anxiety, depression and day- } \\
\text { time sleepiness }\end{array}$ \\
\hline & $\begin{array}{l}\text { "A multidimensional response to } \\
\text { physical, physiological, emotional, } \\
\text { social and financial stressors asso- } \\
\text { ciated with caring for a chronically } \\
\text { ill patient" (p. } 479 \text { ) }\end{array}$ & & No & \\
\hline $\begin{array}{l}\text { Shin et al. } \\
(2012)[63] \\
\text { South Korea }\end{array}$ & $\begin{array}{l}\text { To determine factors that predict } \\
\text { caregiver burden in spousal and } \\
\text { offspring caregiver groups } \\
\text { No definition }\end{array}$ & $\begin{array}{l}91 \text { caregivers } \\
(50 \text { spouses, } \\
41 \text { offspring) }\end{array}$ & $\begin{array}{l}\text { Spearman's rho } \\
\text { Mann-Whitney test } \\
\text { Multiple linear } \\
\text { regression } \\
\text { No }\end{array}$ & $\begin{array}{l}\text { In the spousal group, mentation was } \\
\text { the patient variable that contributed } \\
\text { the most to burden. In the offspring } \\
\text { group, motor function was the patient } \\
\text { variable that most strongly predicted } \\
\text { burden }\end{array}$ \\
\hline $\begin{array}{l}\text { Leroi et al. } \\
(2012)[36] \\
\text { United Kingdom }\end{array}$ & $\begin{array}{l}\text { To explore the relationship be- } \\
\text { tween carer burden and the pres- } \\
\text { ence of apathy and impulse control } \\
\text { disorders (ICD) in PD patients } \\
\text { "The myriad of physical, mental } \\
\text { and socio-economic problems that } \\
\text { arise from caring for an individual } \\
\text { with a chronic and disabling dis- } \\
\text { ease such as PD" (p. 160) }\end{array}$ & $\begin{array}{l}71 \text { caregivers } \\
\text { ( } 38 \text { spouses, } \\
33 \text { adult children) }\end{array}$ & $\begin{array}{l}\text { Linear regression } \\
\text { No }\end{array}$ & $\begin{array}{l}\text { Patient attentional ability accounted } \\
\text { for burden in carers of patients with } \\
\text { apathy. } \\
\text { In carers of patients with ICD dopa- } \\
\text { minergic load and depression ac- } \\
\text { counted for burden. } \\
\text { None of these variables accounted for } \\
\text { carer burden in the PD control group }\end{array}$ \\
\hline $\begin{array}{l}\text { Peters et al. } \\
(2011)[56] \\
\text { United Kingdom }\end{array}$ & $\begin{array}{l}\text { To explore to what extent patient } \\
\text { self-reported health status is asso- } \\
\text { ciated with carer strain and QoL } \\
\text { No definition }\end{array}$ & $\begin{array}{l}704 \text { caregivers } \\
\text { (626 spouses/ part- } \\
\text { ners, } \\
41 \text { children, } \\
18 \text { other family } \\
\text { members, } \\
18 \text { friends or others) }\end{array}$ & $\begin{array}{l}\text { Regression analysis } \\
\text { No }\end{array}$ & $\begin{array}{l}\text { Physical and mental scores of the } \\
\text { SF-36 and years since diagnosis } \\
\text { correlated with caregiver strain. Mo- } \\
\text { bility and social support were the } \\
\text { main patient self-reported PDQ-39 } \\
\text { domains predicting caregiver strain }\end{array}$ \\
\hline $\begin{array}{l}\text { Razali et al. } \\
(2011)[39] \\
\text { Malaysia }\end{array}$ & $\begin{array}{l}\text { To investigate clinical and } \\
\text { socio-demographic factors associ- } \\
\text { ated with perceived burden among } \\
\text { PD caregivers } \\
\text { Caregivers' perceptions of their } \\
\text { health, social life and financial } \\
\text { status suffered because of their } \\
\text { caregiving experience }\end{array}$ & $\begin{array}{l}115 \text { caregivers } \\
(51 \text { spouses, } \\
56 \text { children, } \\
8 \text { other relatives })\end{array}$ & $\begin{array}{l}\text { Correlation } \\
\text { Analysis of vari- } \\
\text { ance } \\
t \text {-test } \\
\text { No }\end{array}$ & $\begin{array}{l}\text { Caregiver burden correlated posi- } \\
\text { tively with patient PD stage and } \\
\text { patient age. Caregiver burden was } \\
\text { also related to her/his race }\end{array}$ \\
\hline $\begin{array}{l}\text { Carter et al. } \\
(2010)[26] \\
\text { USA }\end{array}$ & $\begin{array}{l}\text { To compare the difference in } \\
\text { negative and positive aspects of } \\
\text { strain in young versus older } \\
\text { spouse caregivers in early stage } \\
\text { PD patients } \\
\text { Role strain-difficulty in fulfilling } \\
\text { the caregiving role }\end{array}$ & $\begin{array}{l}65 \text { caregivers } \\
\text { [Spouses, } \\
37 \text { young }(40-55 \\
\text { years }), 28 \text { old }(\geq 70 \\
\text { years })]\end{array}$ & $\begin{array}{l}t \text {-test } \\
\text { Chi-square test } \\
\text { Hierarchical re- } \\
\text { gression analyses } \\
\text { Yes }\end{array}$ & $\begin{array}{l}\text { Compared to the older spouses the } \\
\text { younger group reported significantly } \\
\text { more strain from the negative vari- } \\
\text { ables such as lack of personal re- } \\
\text { sources but not from worry and } \\
\text { global strain. } \\
\text { When controlling for spouse gender } \\
\text { and physical health, the younger } \\
\text { spouses explained } 13 \% \text { of the vari- } \\
\text { ance in strain from lack of personal } \\
\text { resources }\end{array}$ \\
\hline $\begin{array}{l}\text { Leiknes et al. } \\
(2010)[33] \\
\text { Norway }\end{array}$ & $\begin{array}{l}\text { To investigate caregiver distress } \\
\text { associated with neuropsychiatric } \\
\text { problems in patients with newly } \\
\text { diagnosed PD and a control group } \\
\text { "The emotional caregiver distress } \\
\text { associated with the mental health } \\
\text { status of the patients" (p. 419) }\end{array}$ & $\begin{array}{l}189 \text { caregivers } \\
(134 \text { spouses, } \\
31 \text { children, } \\
18 \text { other relatives, } \\
6 \text { others })\end{array}$ & $\begin{array}{l}\text { Mann-Whitney U } \\
\text { test } \\
\text { Chi-square test } \\
\text { Spearman's rho } \\
\text { Yes }\end{array}$ & $\begin{array}{l}\text { PD patients' next of kin reported } \\
\text { significantly more distress than the } \\
\text { non-PD control group. } \\
\text { Female caregivers reported more } \\
\text { symptoms associated with distress. } \\
\text { Only depression and apathy dis- } \\
\text { tressscores of the NPI correlated with } \\
\text { the patient disease stage }\end{array}$ \\
\hline
\end{tabular}




\section{Continued}

Lyons et al. (2009) [25] USA pessimism, mutuality, and spouse gender in predicting role strain in $\mathrm{PD}$ spouses over a 10-year period

Role strain-difficulty fulfilling the family care role

Sarandol et al. (2009) [34] Turkey

To determine factors that increase caregiver burden and depression and to investigate if adult children
To examine the roles of optimism, and spouses differ in their perception of burden

"The extent to which caregivers perceive that their health and social life are adversely affected because of their caregiving" ( $p$. 92)

Stella et al. (2009) [51] Brazil

To identify the impact of patient neuropsychiatric symptoms on caregiver burden

No definition
118 caregivers

(Spouses )

57 caregivers

(35 spouses,

22 adult children)

50 caregivers

(Not given)

given)

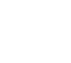

Multilevel modelling

Yes

Mann-Whitney

$U$-Test

Stepwise regression analysis

No

Pearson's product moment correlation Analysis of variance

No

Hierarchical regression analyses

Yes

\section{9 caregivers} tween specific clinical motor and non-motor symptoms in early and middle stage PD to caregiver strain and depression

No definition

Goldsworthy and To examine the relationships Knowles (2008) between caregiver stressors, and [41] Australia protective factors associated with caregiver burden and quality of life

\section{No definition}

Martinez-Martin To analyse the association beet al. (2008) [9] tween the characteristics of paSpain tients with PD and their caregivers and caregiver burden, perceived health and mood status, and to identify their predictors

A concept linked to external aspects dependent on the patient, the environment and personal characteristics

Aarsland et al. (2007) [47]

Norway
136 caregivers

(81.6\% spouses

$88.2 \%$ cohabitants)

Path analysis

No

286 caregivers

(217 spouses,

39 children

23 other relatives,

7 others)

Multivariate linear regression based on factor analysis

No

537 caregivers (Not reported)
To explore the profile of neuropsychiatric symptoms in PD patients with dementia

No definition
Analysis of variance based on cluster analysis

Yes
Female gender predicted both higher role strain at Year 10 and a more rapid increase in role strain over the 10 -year period when controlled for stage of PD and caregiver spouse age. Higher disease stage predicted role strain at Year 10, but not more rapid increases over this period

Female caregivers compared to male caregivers and adult child caregivers compared to spouse caregivers experienced significantly higher burden.

Patient's depression and behavioural disturbances were determinants of caregiver burden

Caregiver burden was proportional with the degree of neuropsychiatric symptomatology. Caregiver burden was significantly lower in caregivers of non-depressed/non-demented patients compared to caregivers of patients with depression or dementia

Patient cognitive impairment and depression have a much greater impact on caregiver strain than the motor symptoms in early and middle stage PD

The caregiver stressors; patient behavioural problems and functional dependency contributed to caregiver burden. Patient cognitive impairment and hours of caregiving did not

All patient-related factors (including mood, autonomic dysfunction, pain, fatigue, disease duration, disability, motor complication, sleep disorders, age and cognition) were predictors of caregiver burden
Based on a cluster analysis of associated neuropsychiatric symptoms in patients, the highest caregiver distress score was observed in the agitation cluster followed by the psychosis and the mood clusters 


\section{Continued}

Kim et al. (2007) To elucidate subjective and objec-<smiles>[131In]</smilestive burden on primary PD- caregivers and identify related factors. South Korea
"Subjective burden refers to the effect and perception components of caregiver burden" (p. 244)

"Objective burden refers to the extent to which the demands of caregiving infringe on the caregiver's time for self and others" (p. 244)

Martinez-Martin et al. (2007) [37] Spain (2006) [62] United Kingdom

To assess caregiver burden and associated factors

116 caregivers (Partners)

No definition (31 spouses, 21 children, 14 other family members, 2 unknown)

To assess the burden and HRQoL 79 caregivers of PD caregivers and to determine (61 spouses, the relationship between these and 15 children, socio-demographics, emotional, 3 others) functional factors and HRQoL

"The realm of physical, mental and socioeconomic problems experienced by the caregivers of chronic patients" (p. 924)
68 caregivers

Marsh et al. (2004) [50] USA

To determine the prevalence and impact of psychiatric comorbidities in PwPD with psychosis

No definition (2002) [31]

To identify various factors in PD
Caap-Ahlgren and Dehlin Sweden patients and their caregivers that are of importance for caregiver burden

"Comprising subjective factors such as feelings of stress or strain, increased health problems and decreased feelings of well-being, and objective factors such as task burden, financial burden and behavioural problems" (p. 83)

Thommessen et al. (2002) [30] Norway
To compare the psychosocial burden on spouses caring for patients with mild dementia, stroke and PD and to identify associated patient characteristics

"The strain or load on people caring for an elderly member of the family" (p. 79)
Pearson's product Subjective burden correlated with the moment correlation caregiver variables age $(\leq 40$ years Analysis of vari- reported less), andrelation to care ance

Kruskal-Wallis recipient (spouses reported highest) and with the patient variables motor disability, disease duration $(<1$ and $>10$ years reported less)and monthly medical costs.

Objective burden correlated with patient motor disability and disease severity
Stepwise multiple regression based on factor analysis

No

50 caregivers (Not reported)

65 caregivers (58 spouses, 3 daughters, 2 sons, 1 brother, 1 niece)

58 caregivers (Spouses)

Multivariate modelling based on factor and path analysis

Yes
Clinical aspects of PD were the main patient variables predicting caregiver burden, followed by patients' mood and HRQoL
Pearson's product moment correlation Spearman's rho

No

Increased PD disability and hallucination, confusion and falls were most strongly correlated with caregiver burden.

Correlation was also found between caregivers' burden and patients' depression, disease duration and $\mathrm{QoL}$

Stepwise linear regression

No

Psychosis was the major predictor of caregiver burden, followed by patient functional ability

Multivariate regression analyses

No

Patient's functional status assessed by $\mathrm{H} \& \mathrm{Y}$ was the most important patient variable for caregiver burden in the multivariate analysis
The regression model disclosed an effect on PD spouses psychosocial burden from the patients' depressive symptoms and lower levels of cognitive function, but not from their ADL function 


\section{Continued}

\begin{tabular}{|c|c|c|c|c|}
\hline $\begin{array}{l}\text { Aarsland et al. } \\
(1999)[29] \\
\text { Norway }\end{array}$ & $\begin{array}{l}\text { To determine the emotional and } \\
\text { social distress of caring for a per- } \\
\text { son with PD and to explore the } \\
\text { impact of motor and mental } \\
\text { symptoms of PD on caregivers' } \\
\text { situation }\end{array}$ & $\begin{array}{l}58 \text { caregivers } \\
\text { (Spouses) }\end{array}$ & $\begin{array}{l}\text { Stepwise multiple } \\
\text { linear regression } \\
\text { Yes }\end{array}$ & $\begin{array}{l}\text { Patient mental symptoms were the } \\
\text { most powerful predictors of caregiver } \\
\text { stress in PD spouses. Patient func- } \\
\text { tional impairment also contributed to } \\
\text { the model whereas severity of motor } \\
\text { symptoms and disease stage did not }\end{array}$ \\
\hline & $\begin{array}{l}\text { "Distress and social upset experi- } \\
\text { enced by the relative as a result of } \\
\text { having to care for an elderly per- } \\
\text { son with physical and/or behav- } \\
\text { ioural disability" (p. 867) }\end{array}$ & & & \\
\hline $\begin{array}{l}\text { Mc Rae et al. } \\
(1999)[11] \\
\text { USA }\end{array}$ & $\begin{array}{l}\text { To investigate sources of distress } \\
\text { in PD caregivers and the relation- } \\
\text { ships between demographic char- } \\
\text { acteristics, stress and family func- } \\
\text { tioning }\end{array}$ & $\begin{array}{l}50 \text { caregivers } \\
\text { (Not reported) }\end{array}$ & $\begin{array}{l}\text { Multivariate analy- } \\
\text { sis of variance } \\
\text { Yes }\end{array}$ & $\begin{array}{l}\text { Aspects of caregiving related to care- } \\
\text { giver's personal concerns and anxiety } \\
\text { were reported to be the most dis- } \\
\text { tressing }\end{array}$ \\
\hline & No definition & & & \\
\hline $\begin{array}{l}\text { Carter et al. } \\
(1998)[27] \\
\text { USA }\end{array}$ & $\begin{array}{l}\text { To examine the experience of } \\
\text { spouses who provide care for } \\
\text { patients with PD and to determine } \\
\text { whether their experiences differed } \\
\text { by stage of disease } \\
\text { No definition }\end{array}$ & $\begin{array}{l}380 \text { caregivers } \\
\text { (Spouses) }\end{array}$ & $\begin{array}{l}\text { Analysis of vari- } \\
\text { ance } \\
\text { Yes }\end{array}$ & $\begin{array}{l}\text { Caregiver strain is experienced across } \\
\text { all stages of PD and increases sig- } \\
\text { nificantly in line with the progression } \\
\text { of the disease }\end{array}$ \\
\hline $\begin{array}{l}\text { Calderet al. } \\
\text { (1991) [64] } \\
\text { United Kingdom }\end{array}$ & $\begin{array}{l}\text { To determine the characteristics of } \\
\text { PD patients that are associated } \\
\text { with stress for their relatives } \\
\text { No definition }\end{array}$ & $\begin{array}{l}65 \text { caregivers } \\
(62 \text { spouses, } \\
2 \text { daughters, } \\
1 \text { daughter in law) }\end{array}$ & $\begin{array}{l}\text { Stepwise regression } \\
\text { analyses } \\
\text { Analysis of Co- } \\
\text { variance } \\
\text { No }\end{array}$ & $\begin{array}{l}\text { Patient's behavioural disturbances } \\
\text { contributed most to the variation in } \\
\text { level of stress, followed by male sex } \\
\text { in patient, patient's self-care and } \\
\text { young age. } \\
\text { Patient's functional disability pre- } \\
\text { dicted relative's stress independently } \\
\text { ofpatient cognitive impairment or } \\
\text { dementia }\end{array}$ \\
\hline
\end{tabular}

*When multivariate procedures are used, these are the only reported except when bivariate analyses show differences between groups.

HRQoL: Health-Related Quality of Life, ICD: Impulse Control Disorder, NPI: Neuropsychiatric Inventory, NPI-CD: Neuropsychiatric Inventory-Caregiver Distress Scale, PD: Parkinson's disease, PDD: Parkinson's Disease Dementia, PD-MCI: Patients with Parkinson's disease-mild cognitive impairment, PD-NC: Patients with Parkinson's disease-no cognitive impairment, PDQ-39: 39-item Parkinson's Disease Questionnaire, Qol: Quality of Life, SF-36: Short Form (36) Health Survey.

mographic and clinical characteristics examined in the studies regarding their possible influence on caregiver burden. The second author (UTL) made some spot tests to cross-check the validity of the latter extraction. In addition, the various instruments used to assess patient characteristics were collected.

\subsection{Data Synthesis}

Data from the included studies were narratively synthesized. A narrative approach was used in preference to a meta-analysis due to the heterogeneity of the studies with a huge variety of instruments applied to assess clinical aspects of PD and caregiver burden outcomes [21].

\subsection{Assessment of Methodological Quality}

Two of the authors (ES/IL) independently assessed the methodological quality of the studies using a modified version of the Norwegian Knowledge Centre for the Health Services (NOKC) check-list for cross-sectional studies [22]. The check-list is a tool for assessing the degree to which the methodology of the studies reduces the risk of systemic bias. It contains seven questions assessing criteria such as 1) population, 2) sampling methods, 3) comparison of respondents and non-respondents, 4) response rate, 5) data collection procedures, 6) reliability and validity and 7) statistical methods. For the purpose of this review, the check-list was supplemented by an 
additional criterion; ethical considerations (Criterion 8). The response alternatives for all questions were Yes (Y), No (N) and No information (NI) (Table 2). Differences in judgment between the two reviewers were resolved

Table 2. Methodological quality assessmentof the included studies.

\begin{tabular}{|c|c|c|c|c|c|c|c|c|c|}
\hline \multirow{2}{*}{ First author (Year) [Reference] } & \multicolumn{8}{|c|}{ Quality assessment question ${ }^{*}$} & \multirow{2}{*}{ Total assessment quality ${ }^{* *}$} \\
\hline & 1 & 2 & 3 & 4 & 5 & 6 & 7 & 8 & \\
\hline Agrawal (2012) [35] & $\mathrm{Y}$ & $\mathrm{Y}$ & $\mathrm{N}$ & NI & $\mathrm{Y}$ & NI & $\mathrm{Y}$ & $\mathrm{Y}$ & Acceptable \\
\hline CaapAhlgren (2002) [31] & $\mathrm{Y}$ & $\mathrm{Y}$ & $\mathrm{Y}$ & $\mathrm{Y}$ & $\mathrm{N}$ & $\mathrm{Y}$ & $\mathrm{Y}$ & $\mathrm{Y}$ & Acceptable \\
\hline Calder (1991) [64] & $\mathrm{Y}$ & $\mathrm{Y}$ & $\mathrm{N}$ & $\mathrm{Y}$ & NI & NI & $\mathrm{Y}$ & $\mathrm{Y}$ & Acceptable \\
\hline Carod-Artal (2013) [61] & $\mathrm{Y}$ & $\mathrm{Y}$ & $\mathrm{N}$ & $\mathrm{Y}$ & NI & $\mathrm{Y}$ & $\mathrm{Y}$ & $\mathrm{Y}$ & Acceptable \\
\hline Carter (1998) [27] & $\mathrm{Y}$ & $\mathrm{Y}$ & $\mathrm{Y}$ & $\mathrm{Y}$ & $\mathrm{Y}$ & $\mathrm{Y}$ & $\mathrm{Y}$ & $\mathrm{Y}$ & Acceptable \\
\hline Carter (2008) [28] & $\mathrm{Y}$ & $\mathrm{Y}$ & $\mathrm{Y}$ & $\mathrm{Y}$ & $\mathrm{Y}$ & $\mathrm{Y}$ & Y & $\mathrm{Y}$ & Acceptable \\
\hline Carter (2010) [26] & $\mathrm{Y}$ & $\mathrm{Y}$ & $\mathrm{Y}$ & $\mathrm{Y}$ & $\mathrm{Y}$ & $\mathrm{Y}$ & $\mathrm{Y}$ & NI & Acceptable \\
\hline Goldsworthy (2008) [41] & $\mathrm{N}$ & $\mathrm{N}$ & $\mathrm{N}$ & NI & $\mathrm{Y}$ & $\mathrm{Y}$ & $\mathrm{Y}$ & $\mathrm{NI}$ & Low \\
\hline Kelly (2012) [12] & $\mathrm{Y}$ & $\mathrm{Y}$ & $\mathrm{N}$ & $\mathrm{N}$ & $\mathrm{Y}$ & NI & $\mathrm{Y}$ & $\mathrm{Y}$ & Acceptable \\
\hline $\operatorname{Kim}(2007)[32]$ & $\mathrm{Y}$ & $\mathrm{Y}$ & $\mathrm{N}$ & $\mathrm{N}$ & $\mathrm{Y}$ & $\mathrm{Y}$ & $\mathrm{Y}$ & Y & Acceptable \\
\hline Kudlicka (2013) [66] & $\mathrm{Y}$ & $\mathrm{Y}$ & $\mathrm{N}$ & $\mathrm{Y}$ & $\mathrm{Y}$ & NI & Y & $\mathrm{Y}$ & Acceptable \\
\hline Leiknes (2010) [33] & $\mathrm{Y}$ & $\mathrm{Y}$ & $\mathrm{N}$ & $\mathrm{Y}$ & $\mathrm{Y}$ & $\mathrm{Y}$ & $\mathrm{Y}$ & Y & Acceptable \\
\hline Leroi (2012) [36] & $\mathrm{Y}$ & $\mathrm{Y}$ & $\mathrm{N}$ & $\mathrm{NI}$ & NI & NI & $\mathrm{Y}$ & $\mathrm{Y}$ & Acceptable \\
\hline Leroi (2012) [49] & $\mathrm{Y}$ & $\mathrm{Y}$ & $\mathrm{N}$ & $\mathrm{Y}$ & NI & NI & $\mathrm{Y}$ & $\mathrm{Y}$ & Acceptable \\
\hline Lyons (2009) [25] & $\mathrm{Y}$ & $\mathrm{Y}$ & $\mathrm{Y}$ & $\mathrm{Y}$ & NI & $\mathrm{Y}$ & $\mathrm{Y}$ & $\mathrm{NI}$ & Acceptable \\
\hline $\operatorname{Marsh}(2004)[50]$ & $\mathrm{Y}$ & $\mathrm{Y}$ & $\mathrm{N}$ & NI & $\mathrm{Y}$ & NI & $\mathrm{Y}$ & Y & Acceptable \\
\hline Martinez-Martin (2007) [37] & $\mathrm{Y}$ & $\mathrm{Y}$ & $\mathrm{N}$ & NI & NI & $\mathrm{Y}$ & $\mathrm{Y}$ & $\mathrm{Y}$ & Acceptable \\
\hline Martinez-Martin (2008) [9] & $\mathrm{Y}$ & $\mathrm{Y}$ & $\mathrm{N}$ & $\mathrm{N}$ & $\mathrm{Y}$ & $\mathrm{Y}$ & $\mathrm{Y}$ & $\mathrm{Y}$ & Acceptable \\
\hline McRae (1999) [11] & Y & $\mathrm{Y}$ & $\mathrm{Y}$ & $\mathrm{Y}$ & $\mathrm{N}$ & $\mathrm{Y}$ & $\mathrm{Y}$ & NI & Acceptable \\
\hline Oguh (2013) [65] & $\mathrm{Y}$ & $\mathrm{Y}$ & $\mathrm{N}$ & $\mathrm{N}$ & $\mathrm{N}$ & $\mathrm{Y}$ & Y & $\mathrm{Y}$ & Acceptable \\
\hline Ozdilek (2012) [38] & $\mathrm{Y}$ & $\mathrm{Y}$ & $\mathrm{N}$ & $\mathrm{N}$ & $\mathrm{Y}$ & NI & $\mathrm{N}$ & $\mathrm{Y}$ & Low \\
\hline Peters (2011) [56] & $\mathrm{Y}$ & $\mathrm{Y}$ & $\mathrm{N}$ & $\mathrm{N}$ & $\mathrm{Y}$ & NI & $\mathrm{Y}$ & $\mathrm{Y}$ & Acceptable \\
\hline Razali (2011) [39] & $\mathrm{Y}$ & $\mathrm{Y}$ & $\mathrm{Y}$ & $\mathrm{Y}$ & $\mathrm{Y}$ & NI & $\mathrm{N}$ & Y & Acceptable \\
\hline Sarandol (2009) [34] & $\mathrm{Y}$ & $\mathrm{Y}$ & $\mathrm{N}$ & $\mathrm{N}$ & NI & NI & $\mathrm{N}$ & $\mathrm{Y}$ & Low \\
\hline Schrag (2006) [62] & $\mathrm{Y}$ & $\mathrm{N}$ & $\mathrm{N}$ & NI & $\mathrm{Y}$ & NI & Y & Y & Low \\
\hline Shin (2012) [63] & $\mathrm{Y}$ & $\mathrm{Y}$ & $\mathrm{N}$ & $\mathrm{N}$ & $\mathrm{Y}$ & NI & $\mathrm{Y}$ & $\mathrm{NI}$ & Low \\
\hline Stella (2009) [51] & $\mathrm{Y}$ & $\mathrm{Y}$ & $\mathrm{N}$ & $\mathrm{N}$ & $\mathrm{Y}$ & NI & Y & $\mathrm{Y}$ & Acceptable \\
\hline Tanji (2013) [54] & $\mathrm{Y}$ & $\mathrm{Y}$ & $\mathrm{Y}$ & $\mathrm{Y}$ & $\mathrm{Y}$ & $\mathrm{Y}$ & $\mathrm{Y}$ & $\mathrm{Y}$ & Acceptable \\
\hline Thommesen (2002) [30] & $\mathrm{Y}$ & $\mathrm{Y}$ & $\mathrm{Y}$ & $\mathrm{Y}$ & NI & $\mathrm{Y}$ & $\mathrm{Y}$ & $\mathrm{Y}$ & Acceptable \\
\hline Aarsland (1999) [29] & $\mathrm{Y}$ & $\mathrm{Y}$ & $\mathrm{Y}$ & $\mathrm{Y}$ & $\mathrm{Y}$ & $\mathrm{Y}$ & Y & Y & Acceptable \\
\hline Aarsland (2007) [47] & $\mathrm{Y}$ & $\mathrm{Y}$ & $\mathrm{N}$ & $\mathrm{Y}$ & $\mathrm{Y}$ & $\mathrm{Y}$ & $\mathrm{Y}$ & $\mathrm{Y}$ & Acceptable \\
\hline
\end{tabular}

Note: $\mathrm{Y}=$ yes; $\mathrm{N}=$ no; $\mathrm{NI}=$ no information.

${ }^{*}$ Quality assessment questions

1. Was the population from which the sample was drawn clearly defined?

2. Were sampling methodsadequate?

3. Was it explained whether (and how) the participants who agreed to participate differed from those who refused?

4. Was the response rate adequate?

5. Were procedures for data collection standardized?

6. Were measures shown to be reliable and valid?

7. Were the statistical methods appropriate?

8. Wereethicalissuesconsidered?

${ }^{* *}$ Studies meeting $>50 \%$ of the criteria rated as acceptable in terms of quality, studies meeting $\leq 50 \%$ of the criteria rated as low quality [22]. 
by re-reading the studies and subsequent discussions. When in doubt, a statistician was consulted for a final decision. Studies that met $>50 \%$ of the criteria were rated as acceptable in quality, whereas those that met $\leq 50 \%$ of the criteria were rated as being of low methodological quality [23]. Finally, 26 out of the 31 studies were deemed to be of acceptable quality. No studies were excluded due to low quality. Methodological shortcomings mainly concerned criteria 3, 4 and 6. Twenty one of the studies failed to explain whether and how the participants who agreed to participate differed from those who refused (criterion 3). Fifteen studies did not achieve an acceptable response rate of $65 \%$ [24], or failed to provide information about the response rate (criterion 4). Fourteen studies did not comment on the validity or reliability of the outcome measure (criterion 6). Ethical issues were considered in 26 of the 31 selected studies (criterion 8).

\section{Results}

\subsection{Study Characteristics}

Thirty one studies published between 1991 and 2014 in English-language journals were included in the review. The studies represent European, North- and South American, as well as Asian countries. Key features of the included studies are described in Table 1. All but one longitudinal study [25] have a cross sectional design. Fifteen were designed as single studies and 16 were sub-studies that emanated from an epidemiological study, a clinical trial or an intervention study. In the sub-studies, data collection was conducted in the original study or new information was collected from the respondents who participated in the original study, or in some cases by recruiting additional participants. Some studies partly share a database with one or more of the other included studies [25]-[28] and [29] [30]. However, they all have separate statistical analyses. In most studies, the caregiver was recruited together with the person she/he cares for. The caregiver sample size ranged from 50 to 2476 , with the majority of studies having less than 100 participants, of whom spouses/partners constituted the main caregiver group. Fifteen studies provide a definition or description of caregiver burden, distress, strain or stress, referring to the concepts' multifaceted nature of external, environmental and personal factors [9], subjective and objective burden [31] [32], emotional distress [33], enduring change of well-being [12], psychosocial load as a result of caring [29] [30], impact on social life and health [34] and difficulties in fulfilling the caregiving role [25] [26]. Five studies [35]-[39] refer to the much cited definition of caregiver burden presented by Zarit et al. [40], which defines it as "the extent to which caregivers perceived their emotional or physical health, social life, and financial status as suffering as a result of caring for their relative" (p. 261). Only one study [41] has an explicitly theoretical approach, based on a stress-appraisal model. Twenty two of the 31 included studies provide multivariate statistical procedures analysing the relationship among three or more variables [24] (multiple regression, analysis of covariance, multivariate analysis of variance, factor analysis, logistic regression and path analysis). Nine studies only provide bivariate statistical tests, analysing the relation between two variables [24] (Person's product moment correlation, Spearman's rho, Mann-Whitney $U$-test, analysis of variance and $t$-test). Nineteen studies report sub-scores of the caregiver burden instruments, whereas 12 only report the sum scores of the burden instruments. Eleven studies use some stratification of the sample in the statistical analysis.

\subsection{Instruments}

Eleven different generic instruments for assessing caregiver burden, distress, strain or stress were identified. The instruments cover a wide range of domains with a variety of items and sub-scales (Table 3). Eleven studies used a caregiver burden instrument based on the ones developed by Zarit et al. [42] [43]. The Caregiver Burden Inventory [44] and The Relative Stress Scale [45] were each used in three studies. Four articles [25]-[28] refer to the caregiver section of the Family Caregiving Inventory [46], although the number of scales and items used vary across studies. One study [47] used the original 10 item version of the Neuropsychiatric Inventory (NPI) [48], whereas four studies [33] [49]-[51] employed the 12 item NPI Caregiver Distress Scale (NPI-CD) [52]. The original Caregiver Strain Index (CSI) [53] was used in the study by Tanji et al. [54], whereas the modified version (MCSI) [55] with an amended response set, was employed by Kelly et al. [12] and Peters et al. [56]. The Care Management Stress Scale [57], the Caregiver Burden Scale [58], The Montgomery, Gonyea and Hooyman's scale [59] and the Multidimensional Caregiver Strain Index [60] were used in only one study each.

Psychometric testing of internal consistency was carried out by means of Cronbach's alpha for all but one instrument. Except for a few sub-scales the Cronbach's alpha level was beyond the acceptable border of 0.70, de- 
Table 3. Instruments assessing the impact of caregiver burden in the included studies.

\begin{tabular}{|c|c|c|c|c|c|c|}
\hline $\begin{array}{l}\text { Name of the instru- } \\
\text { ment } \\
\text { (Abbreviation name) } \\
\text { [Reference] }\end{array}$ & $\begin{array}{l}\text { Items } \\
\text { Format }\end{array}$ & Subscales (items) & $\begin{array}{l}\text { Reliability } \\
\text { [Cronbach alpha }(\alpha) \\
\text { Test-retest } \\
\text { Inter-rater reliability] }\end{array}$ & Validity & $\begin{array}{l}\text { Reliability tested } \\
\text { in PD population } \\
\text { [Reference] }\end{array}$ & [Reference] \\
\hline $\begin{array}{l}\text { Care Management } \\
\text { Stress Scale (CMS) } \\
{[57]}\end{array}$ & $\begin{array}{l}25 \text { items } \\
5 \text {-Point scale }\end{array}$ & No subscales & Not available & Not reported & $\begin{array}{l}\alpha=0.94 \\
{[11]}\end{array}$ & [11] \\
\hline $\begin{array}{l}\text { Caregiver Burden } \\
\text { Inventory (CBI) [44] }\end{array}$ & $\begin{array}{l}24 \text { items } \\
\text { 5-Point scale }\end{array}$ & $\begin{array}{l}\text { Time-dependence burden (5) } \\
\text { Developmental burden (5) } \\
\text { Physical burden (4) } \\
\text { Social burden (5) } \\
\text { Emotional burden (5) }\end{array}$ & $\alpha=0.73-0.86$ & Construct & $\begin{array}{l}\alpha=0.94 \\
{[41]}\end{array}$ & $\begin{array}{l}{[41][62]} \\
{[66]}\end{array}$ \\
\hline $\begin{array}{l}\text { Caregiver Burden } \\
\text { Scale (CBS) } \\
{[58]}\end{array}$ & $\begin{array}{l}22 \text { items } \\
\text { 4-Point scale }\end{array}$ & $\begin{array}{l}\text { General strain (8) } \\
\text { Isolation (3) } \\
\text { Disappointment (5) } \\
\text { Emotional involvement (3) } \\
\text { Environment (3) }\end{array}$ & $\begin{array}{l}\alpha=0.70-0.87 \\
\text { Environment } \alpha= \\
0.53\end{array}$ & Construct & $\begin{array}{l}\alpha=0.88 \\
{[31]}\end{array}$ & [31] \\
\hline $\begin{array}{l}\text { Caregiver Strain } \\
\text { Index (CSI) } \\
{[53]}\end{array}$ & $\begin{array}{l}13 \text { items } \\
\text { Dichotomous } \\
\text { (yes/no) }\end{array}$ & No subscales & $\alpha=0.86$ & Construct & Not reported & {$[54]$} \\
\hline $\begin{array}{l}\text { Family Caregiving } \\
\text { Inventory (FCI) } \\
\text { [46] }\end{array}$ & $\begin{array}{l}102 \text { items } \\
\text { 5-Point scale }\end{array}$ & $\begin{array}{l}\text { Strain from direct care (38) } \\
\text { Strain from lack of resources (6) } \\
\text { Strain from worry (10) } \\
\text { Strain from role conflict }(15) \\
\text { Strain from economic burden (4) } \\
\text { Strain from mismatched expec- } \\
\text { tations (3) } \\
\text { Strain from increased tension (4) } \\
\text { Strain from feelings of being } \\
\text { manipulated (4) } \\
\text { Global strain (4) }\end{array}$ & $\begin{array}{l}\alpha>0.70 \text { for } 6 \text { of } 9 \\
\text { scales for which } \\
\text { Cronbach's alpha } \\
\text { was reported } \\
\alpha<0.55 \text { for strain } \\
\text { from mismatched } \\
\text { expectations } \\
\text { Test-retest reliability } \\
r>0.60\end{array}$ & Not reported & $\begin{array}{l}\alpha=0.75-0.98 \\
\text { except for strain } \\
\text { from mismatched } \\
\text { expectations, } \alpha= \\
0.57 \\
{[27]}\end{array}$ & {$[25]-[28]$} \\
\hline $\begin{array}{l}\text { Modified Caregiver } \\
\text { Strain Index (CSI) } \\
{[55]}\end{array}$ & $\begin{array}{l}13 \text { items } \\
\text { 3-Point scale }\end{array}$ & No subscales & $\begin{array}{l}\alpha=0.90 \\
\text { Test-retest reliability } \\
0.88\end{array}$ & Not reported & Not reported & [12] [56] \\
\hline $\begin{array}{l}\text { Montgomery, Gon- } \\
\text { yea and Hooyman's } \\
\text { scale } \\
{[59]}\end{array}$ & $\begin{array}{l}22 \text { items } \\
5 \text {-Point scale }\end{array}$ & $\begin{array}{l}\text { Subjective burden (13) } \\
\text { Objective burden (9) }\end{array}$ & $\begin{array}{l}\alpha=0.85 \text { (objective } \\
\text { scale) } \\
\alpha=0.86 \text { (subjective } \\
\text { scale) }\end{array}$ & Not reported & Not reported & {$[32]$} \\
\hline $\begin{array}{l}\text { Multidimensional } \\
\text { Caregiver Strain } \\
\text { Index (MCSI) } \\
{[60]}\end{array}$ & $\begin{array}{l}18 \text { items } \\
\text { 5-Point scale }\end{array}$ & $\begin{array}{l}\text { Physical strain (3) } \\
\text { Social constraints (4) } \\
\text { Financial strain (2) } \\
\text { Time constraints (2) } \\
\text { Interpersonal strain (5) } \\
\text { Elder demanding/manipulative } \\
\text { (2) }\end{array}$ & $\begin{array}{l}\alpha=0.75-0.85 \\
\text { Financial Strain } \\
\alpha=0.58\end{array}$ & $\begin{array}{l}\text { Construct } \\
\text { Criterion }\end{array}$ & $\begin{array}{l}\alpha=0.855 \text { for total } \\
\text { MCSI } \\
{[65]}\end{array}$ & {$[65]$} \\
\hline $\begin{array}{l}\text { Neuropsychiatric } \\
\text { Inventory Caregiver } \\
\text { Distress Scale } \\
\text { (NPI-CD) } \\
\text { [52] }\end{array}$ & $\begin{array}{l}12(10) \text { items } \\
\text { 6-Point scale }\end{array}$ & No subscales & $\begin{array}{l}\text { Test-retest reliability } \\
\mathrm{r}=0.92 \\
\text { Interrater reliability } \\
0.96\end{array}$ & Criterion & Not reported & $\begin{array}{l}{[33][47]} \\
{[49]-[51]}\end{array}$ \\
\hline $\begin{array}{l}\text { Relative Stress Scale } \\
\text { (RSS) } \\
\text { [45] }\end{array}$ & $\begin{array}{l}15 \text { items } \\
\text { 5-Point scale }\end{array}$ & $\begin{array}{l}\text { Personal distress ( } 6 \text { ) } \\
\text { Life Upset (5) } \\
\text { Negative feelings (4) }\end{array}$ & $\alpha=0.72-0.88$ & Construct & $\begin{array}{l}\alpha=0.94 \text { for } \\
\text { 'Psychosocial } \\
\text { burden' based on } \\
8 \text { items of the RSS } \\
{[30]}\end{array}$ & $\begin{array}{l}{[29][30]} \\
{[64]}\end{array}$ \\
\hline $\begin{array}{l}\text { Zarit Caregiver Bur- } \\
\text { den Interview (ZBI) } \\
\text { [42] [43] }\end{array}$ & $\begin{array}{l}22 \text { items } \\
\text { (originally } 29 \\
\text { items) } \\
\text { 5-point scale }\end{array}$ & No subscales & Not reported & $\begin{array}{l}\text { Construct } \\
\text { validity } \\
\text { negative }\end{array}$ & $\begin{array}{l}\alpha=0.93 \\
{[37]}\end{array}$ & $\begin{array}{l}{[9][34]-[39]} \\
{[49][50]} \\
{[61][63]}\end{array}$ \\
\hline
\end{tabular}


monstrating the internal consistency of the instruments [24]. In addition, construct and/or criteria validation was reported for six instruments. The validity of the instruments for use in a PD population was further confirmed for seven of the instruments with a Cronbach's alpha $>0.75$ for nearly all scales.

The included studies use various terminologies, including caregiver or carer, burden, distress, strain or stress. In this article we generally use the terms caregiver and burden. When referring to results from one particular article we use that article's own terminology.

\subsection{Demographic and Clinical Characteristics Related to Caregiver Burden}

A range of different instruments was used to assess patient characteristics possibly associated with caregiver burden. These are listed consecutively when mentioned in the text. A summary of the synthesizing of demographics and the association of PD characteristics with caregiver burden is presented in Table 4.

Table 4. Demographic variables and clinical aspects of Parkinson's disease (PD) related to caregiver burden.

\begin{tabular}{|c|c|c|}
\hline Factors & $\begin{array}{l}\text { Number } \\
\text { of studies }\end{array}$ & Key insights \\
\hline \multicolumn{3}{|l|}{ Demographic variables } \\
\hline Gender & 15 & $\begin{array}{l}\text { Patient and caregiver sex has little effect on caregiver burden, although there is a trend that } \\
\text { higher burden scores are associated with female caregivers and male patients }\end{array}$ \\
\hline Relationship & 7 & $\begin{array}{l}\text { There is conflicting evidence as to whether spouses are more burdened than non-spouses. } \\
\text { Spouses and non-spouses tend to differ with respect to the burden domains affected }\end{array}$ \\
\hline Age & 20 & $\begin{array}{l}\text { The influence of patient and caregiver age on caregiver burden emerged when comparing various } \\
\text { caregiver age groups }\end{array}$ \\
\hline Socio-demographic & 5 & Two studies reported cultural variation in caregiver burden \\
\hline \multicolumn{3}{|l|}{$\begin{array}{l}\text { Motor symptoms of } \\
\text { patients }\end{array}$} \\
\hline PD stage & 20 & PD stage is an important predictor of caregiver burden \\
\hline Parkinsonism & 18 & $\begin{array}{l}\text { Many studies report on the relationship between caregiver burden and the motor severity of PD. } \\
\text { Motor severity (apart from disability) is not reported to independently contribute to caregiver } \\
\text { burden. Patient functional ability as assessed by several ADL scales correlates with caregiver } \\
\text { burden. Evidence of the individual effect of functional impairment on caregiver burden is incon- } \\
\text { clusive }\end{array}$ \\
\hline $\begin{array}{l}\text { Falls and motor com- } \\
\text { plications }\end{array}$ & 8 & $\begin{array}{l}\text { Studies reporting on the relationship between caregiver burden and patient motor fluctuations, } \\
\text { involuntary movements and falls confirm the association }\end{array}$ \\
\hline Duration of PD & 11 & $\begin{array}{l}\text { Most studies analysing the relationship between duration of PD and burden report a positive } \\
\text { correlation }\end{array}$ \\
\hline \multicolumn{3}{|l|}{ Non-motor symptoms } \\
\hline Depression & 13 & Depressive symptoms in patients are important contributors to caregiver burden \\
\hline $\begin{array}{l}\text { Anxiety and } \\
\text { apathy }\end{array}$ & 5 & $\begin{array}{l}\text { The relationship between patient anxiety, apathy and caregiver burden is confirmed in a few } \\
\text { studies }\end{array}$ \\
\hline Cognition & 9 & $\begin{array}{l}\text { Patients' mild as well as serious cognitive impairment identified on several generic scales was } \\
\text { related to caregiver burden }\end{array}$ \\
\hline $\begin{array}{l}\text { Psychotic symptoms } \\
\text { and behavioural } \\
\text { disturbances }\end{array}$ & 10 & $\begin{array}{l}\text { A few studies report on the association between patient psychiatric symptoms and caregiver } \\
\text { burden. Patient behavioural problems as assessed by a variety of scales have been found to have } \\
\text { a significant effect on caregiver burden }\end{array}$ \\
\hline $\begin{array}{l}\text { Neuropsychiatric } \\
\text { comorbidity }\end{array}$ & 6 & $\begin{array}{l}\text { In general, neuropsychiatric symptoms have a stronger impact on caregiver burden than motor- } \\
\text { symptoms. Caregivers of patients diagnosed with comorbidities such as depression, apathy, } \\
\text { dementia, psychosis and impulse control disorders reported more burden than caregivers of } \\
\text { patients without such comorbidities }\end{array}$ \\
\hline $\begin{array}{l}\text { Other non-motor } \\
\text { symptoms }\end{array}$ & 6 & $\begin{array}{l}\text { With the exception of neuropsychiatrics, non-motor symptoms are sparsely addressed. Sleep } \\
\text { disturbance is reported as an independent contributor to caregiver burden }\end{array}$ \\
\hline $\begin{array}{l}\text { Patient's Quality of } \\
\text { life }\end{array}$ & 9 & $\begin{array}{l}\text { Several studies demonstrate the association between higher burden scores and decrease in patient } \\
\text { quality of life (QoL) as assessed by both PD specific and generic QoL instruments }\end{array}$ \\
\hline
\end{tabular}




\subsubsection{Demographic Variables}

\section{1) Gender Effects}

Several studies have examined the influence of sex on caregivers' perception of burden in PD. Most studies in the present review, using different caregiver scales and representing European, North- and South American, as well as Asian cultures, did not find a patient or caregiver gender effect on caregiver burden scores [9] [30]-[32] [38] [39] [61]-[63], although some found that female caregivers tend to report more burden [33] [34] [37]. Female sex in spouse caregivers was also found to be a predictor of role strain over a 10 year period, when statistically controlled for the effect of PD stage and spouses' age [25]. Likewise, male sex in the patient revealed a significant association with higher caregiver strain scores in multivariate analysis [64] [65].

\section{2) Relationship}

A few studies explored the association between caregiver burden and caregivers' relationship with the care recipient. In a study reporting on a quality improvement registry including 2476 patient-caregiver couples in the US, spouses/partners (constituting 91\%) were less likely to report higher levels of caregiver strain on the Multidimensional Caregiver Strain Index (MCSI) compared to non-spouses [65]. Likewise, in a small-size Turkish study $(\mathrm{n}=57)$, adult child caregivers reported significantly higher sum scores and personal and role strain sub-scores on the Zarit burden Inventory (ZBI) than spouse caregivers, even without any significant differences in terms of caregiving characteristics [34]. Two Asian studies [39] [63] as well as another Turkish one [38], also using the ZBI, found no statistically significant differences in burden scores between spouses and non-spouses, although factors contributing to caregiver burden differed between spouses and offspring in the study by Shin et al. [63]. In addition, in a South Korean study [32] subjective burden, referring to the affective and perceived changes in life due to caregiving activities, was higher in the spousal group compared to non-spouses, whereas objective burden, defined as how caregivers perceive the disruption caused to their life by caregiving, did not differ between spouses and non-spouses. Moreover, in a Norwegian study spouses reported higher levels of caregiver stress on the "Life upset" subscale of the Relative Stress Scale (RSS) compared to non-spouses, whereas there were no differences between the caregiver groups regarding the RSS "Negative feelings" and "Personal distress" subscales [29].

3) Age

Many studies across various continents have found that caregiver burden is unrelated to patient and/or caregiver age [11] [12] [29]-[31] [36] [38] [49] [54] [61] [63] [66] even after adjustment for disease duration [62]. Nevertheless, age may matter in PD caregiving. In a multi-centre North American study [26] younger spouses (40 - 55 years) compared to older spouses (>70 years) reported more strain from the role strain dimension "Lack of personal resources" but not from the dimensions "Strain from worry" and "Global strain". In this study a significant amount of the variance of strain from 'Lack of personal resources' was explained by age [26]. Unlike in the South Korean study by Kim et al. [32], which compared even younger caregivers ( $\leq 40$ years) with groups of older ( 41 - 64 years and $\geq 65$ years) caregivers, the youngest reported significantly lower subjective burden than the older ones, with the eldest reporting the most burden. In addition, Calder [64] found that young age in patients contributed to the variation in levels of stress in a group of Scottish PD relatives (mainly spouses). No correlation was reported between age at PD onset and burden scores [35] [36] [39] [51], except in a subgroup of caregivers of PD patients with dementia [51] and in a study by Martinez-Martin et al. [37].

\section{4) Sociodemographic Factors}

Marital status, educational level, as well as occupational and financial status were seldom addressed in the identified studies and not found to be associated with caregiver burden [34] [38] [63]. Two studies [39] [54] reported cultural variation in caregiver strain. In a Malaysian study a significant difference in mean burden score was found between caregivers representing four different races [39]. In contrast, the caregiver strain sum scores were equal in a comparative study of Japanese and US spouse caregivers. However, the Japanese group disclosed significantly more burden on single items related to time demands and physical and financial strain on the Caregiver Strain Index, while the US group scored higher on emotional strain items [54].

\subsubsection{Motor Symptoms}

\section{1) PD Stage}

The relationship between caregiver burden and severity of PD as assessed by the Hoehn \& Yahr (H \& Y) disease stage scale [67] was thoroughly documented in the identified studies [9] [29] [31] [32] [35]-[39] [49] [51] [54] [61] [63]-[66] [68]. Caregiver strain has been reported at all stages of PD [27] and burden scores increase 
significantly in line with advancing H \& Y stage [27] [35] [61]. PD stage was found to be an important predictor of caregiver burden scores in multivariate analysis [31] [65] [66], even after controlling for sex and cognitive deterioration [64]. In addition, caregivers of patients with a higher disease stage at baseline were more likely to report superior levels of certain role strain variables ("global strain" and "strain from worry") after 10 years [25].

\section{2) Parkinsonism}

Correlation analyses between caregiver burden and the severity of Parkinsonism as measured by the Unified Parkinson's Disease Rating Scales [69]-motor scale (UPDRS III) and the motor scale of the Scales for Outcomes in Parkinson's Disease (SCOPA-Motor) [70] confirms the association between disease severity of PD and increased burden scores [9] [29] [35] [36] [38] [49] [61] [63]. Likewise, correlation analysis between sum scores on different caregiver burden scales and functional ability as assessed by various activity of daily living (ADL) scales including the UPDRS II, Schwab \& England ADL scale (S \& E) [71], ADL subscale of The SCOPA-Motor (SCOPA-ADL) [70], Barthel Index (BI) [72] and Reported Self Care Scale (RSCS) [73] supports the reported relationship between caregiver burden and severity of Parkinsonism [30] [32] [37] [38] [51] [54] [62] [63]. Several studies report the effect of functional disability on the overall caregiver burden based on multivariate analysis [9] [41] [50] [64]. In the study by Aarsland et al. [29], functional impairment (S \& E) contributed to the spouses' "Personal distress" scores as assessed by the RSS but not to the 'Negative feelings' and 'Life upset' subscales. Other studies found no effect of patient ADL function in multivariate analysis [28] [30] [35] [54] [61] [63]. Severity of motor symptoms was found to be an independent predictor of caregiver burden in the study by Agrawal et al. [35] and a subgroup of offspring caregivers in the study by Shin et al. [63].

\section{3) Falls and Motor Complications}

The incidence of falls, a key variable of functional impairment in PD [74], is sparsely examined in a caregiving context. However, in one study [62] patient falls were strongly associated with burden in caregiver partners. Likewise, in the large scale US registry study [65], a higher frequency of falls was associated with greater levels of caregiver strain. In the comparative study of strain between caregiver spouses in Japan and the US, multivariate analysis revealed falls to be a predictor of caregiver strain in the Japanese group, but not in the US group [54]. Beyond this, a few studies report a positive correlation between caregiver burden and the presence of motor complications such as motor fluctuations and/or involuntary movements [9] [35] [36] [38] [62] [63] [65]. In the study by Shin et al. [63] a correlation was found in caregiver spouses but not in offspring.

\section{4) Duration of PD}

While several studies have observed a positive correlation between duration of PD and higher burden scores [9] [25] [31] [35] [56] [62] [65], Kim et al. [32] found the emotional (subjective) burden to be highest 1 - 5 years after the patients received their PD diagnosis. Additionally, two studies could not identify a significant correlation between PD duration and caregiver burden [37] [51]. When comparing caregiver strain in a Japanese and a US cohort, PD duration correlated with caregiver strain in the US cohort, but not in the Japanese [54].

\subsubsection{Non-Motor Symptoms}

\section{1) Depression}

Depression is the mental symptom in PD most often examined in a caregiver burden context. A range of self-report and interview instruments were used to explore the relationship between patient depression and caregiver burden, including the Beck Depression Inventory [75], Brief Symptom Inventory [76], Center for Epidemiological Studies Depression Scale [77], Geriatric Depression Scale [78], Hamilton Depression Rating Scale [79], Hospital Anxiety and Depression scale [80] and Montgomery-Aasberg Depression Rating Scale [81]. Several studies using various combinations of depression scales and burden instruments report positive correlations [9] [30] [31] [38] [54] [61] [62] [66] and the predictive power of depression on caregiver burden [28]-[30] [34][36] [54].

\section{2) Anxiety and Apathy}

Patient anxiety and apathy was sparsely addressed in the reviewed studies. Nevertheless, patient apathy was among the most frequently reported neuropsychiatric symptoms to be associated with caregiver distress on the NPI-D in a cohort of newly diagnosed PD patients [33] and a study of PD patients with dementia (PDD) [47]. Three studies report a positive correlation between patient anxiety and caregiver burden scores [37] [38] [61].

\section{3) Cognition}

In PD, even early detectable cognitive impairment assessed by testing the patient's verbal fluency and delayed 
word recall [82], were associated with higher levels of strain in caregivers [28] [65]. The contribution of delayed recall was significant for five of the six role strain variables assessed in the study by Carter et al. [28] ("global strain", "strain from worry", "manipulation", "tension" and "strain from frustration due to communication problems"). In the study by Kudlicka et al. [66] caregiver rated executive function impairment, a common cognitive deficit observed in the early stages of PD [83], was the strongest predictor of caregiver burden. The relationship between impaired global cognition in the patient and higher burden scores is further supported by bivariate [54] [63] and multivariate analysis [9] [29] [30] [49] using the generic Mini Mental State Examination [84] or the PD specific Scales for Outcomes in Parkinson's disease-cognition scale [85].

\section{4) Psychotic Symptoms and Behaviour Disturbances}

Psychotic symptoms as assessed by the Parkinson Psychosis Rating Scale [86] have a moderate correlation [9] and make an independent contribution [61] to caregiver ZBI scores. Likewise, hallucination and confusion in the patient were among the key symptoms that PD partners associated most strongly with caregiver burden as assessed on the Caregiver-burden Inventory in the study by Schrag et al. [62], whereas no correlation was found in a mixed group of PD caregivers (50\% spouses) [35] on the ZBI. In an international multicentre study of PDD caregivers who were clustered on the basis of the patient's NPI symptoms [47], caregivers of the psychosis group (characterized by high scores on visual hallucinations and delusions) exhibited the second highest caregiver distress (NPI-CD) sum score after the agitation group (including irritability and agitation). In addition, behavioural problems in PD, as identified by the sum scores on the CAPE Behavior Rating Scale [87], Behavioral Problems Scale [88], Behavior Rating Inventory of Executive Function [89] and the Behavior Pathology of Alzheimer's Disease Frequency Weighted scale [90], have been demonstrated by regression analyses to have a significant effect on various caregiver burden measures [34] [41] [64] [66].

\section{5) Neuropsychiatric Comorbility}

Caregivers of PD patients diagnosed with psychosis [50], impulse control disorders [36], dementia [51] and apathy [36] reported significantly higher burden scores compared to caregivers of patients without neuropsychiatric comorbidity. Likewise, patient depression generated a higher caregiver burden compared to non-depressed patients [51] also when controlled for the effect of patient ADL-scores [37]. ADL-scores in addition to patient age were also controlled for in the study by Leroi et al. [49], who found a significantly greater burden on the ZBI scale of the caregivers of PDD patients compared to non-demented patients. However, no difference between the caregiver groups was observed on the NPI-CD scale in the same study. In the study by Calder et al. [64], the observed differences in stress scores (RSS) between caregivers of patients with and without dementia, were non-significant after controlling for the effect of disability as assessed by H\&Y stage. Nevertheless, the influence of patients' neuropsychiatric status on caregiver burden is well documented in the studies, indicating that in regression analyses neuropsychiatric symptoms have a stronger impact on caregiver burden than motor symptoms or functional impairment [28]-[30] [34] [35] [50] [61].

\subsubsection{Other Non-Motor Symptoms}

Non-motor problems such as patient fatigue, autonomic dysfunction, pain and sleep disturbance are sparsely addressed in relation to caregiver burden in PD. One study [61], reporting the sum scores of the Non-motor Symptom Assessment Scale for Parkinson's Disease [91], which covers nine non-motor domains, found a moderate association with the ZBI sum score. In the study by Agrawal et al. [35] sleep disturbances in patients, but not autonomic symptoms, were identified as a significant predictor of caregiver burden after regression analysis. In the study by Martinez-Martin et al. [9], a range of patient-related variables were embedded in factor analysis, resulting in 4 factors of which one included autonomic dysfunction, pain and fatigue, while a second was linked to sleep disorders. Both factors had an independent impact on caregiver burden [9]. Several other studies report a positive correlation [38] or an independent contribution of patient sleep problems on caregiver burden [35] [61]. Unexpectedly, in the only two studies reporting correlations between caregiver strain and unspecific patient comorbidity, the latter did not relate to the level of caregiver strain [65] and was not associated with caregiver strain after regression analysis [54].

\subsubsection{Patients' Quality of Life}

Several studies [12] [31] [56] [62] [65] demonstrate an association between higher caregiver burden and a decrease in patient self-reported QoL, based on the sum score of the 39-item Parkinson's Disease Questionnaire (PDQ-39) [92]. In Peters et al. [56] the PDQ-39 subscales Mobility and Social Support were identified as the 
most likely to affect the Caregiver Strain Index scores, when adjusted for duration of disease, years spent as a caregiver, hours spent on caring per week and the sex of patient and caregiver. PDQ-mobility was also the subscale associated with a high caregiver strain score on the Multidimensional Caregiver Strain Index in the US registry study [65], followed by the PDQ-39 emotional subscale. The relation between caregiver burden and patient QoL is further confirmed when using the generic EuroQoL [93], [9] [12] [37] [61] and the 12-item Short Form Health Survey, version 2 (SF-12v2) [94] [56], which was expected due to the observed positive correlation of these scales with the PDQ-39 [56] [62]. In a recently published study Kudlicka et al. [66] claimed that questionnaires used for assessing QoL tend to ask about self-assessed health status rather than the person's subjective satisfaction with life. Accordingly, the authors supplemented the PDQ-39 by the Question on Life Satisfaction scale (QLS) [95], which includes three domains: general life satisfaction, satisfaction with health and satisfaction with health in relation to movement disorders. Despite a strong correlation between PDQ-39 sum scores and the QLS health and movement disorders subscales, caregiver burden assessed by the Caregiver Burden Inventory correlated with the PDQ-39, but was not related to the QLS domains [66].

\section{Discussion}

Analysis of the included studies revealed great variation in how the impact of clinical characteristics on caregiver burden is studied in a PD setting. Eleven caregiver burden instruments were identified in the 31 reviewed articles, with the ZBI being the most frequently used. In addition, a large number of different scales were employed to identify specific characteristics that may influence caregiver burden. Consequently, many combinations of instruments were involved in the statistical analyses, making it difficult to review the results in a systematic way. Most studies only report on the association of patient related factors with the sum score of caregiver burden instruments. A few provide analyses of the subgroups of a heterogeneous study sample. All studies with the exception of one had a cross-sectional design. Accordingly, there is a lack of knowledge about the progression of burden in PD caregiving and the factors that influence burden over time.

\subsection{How Did the Demographic and Clinical Characteristics of Patients with PD Influence Caregiver Burden?}

Despite the great variety of instruments used in the analysis, similar associations were found between caregiver burden, demographic variables and certain patient characteristics across the reviewed studies. There is clear statistical evidence of the relationship between the severity of PD and increased caregiver burden. In particular, higher PD stage and patients' problems performing ADL contribute to caregivers' burden. Duration of PD, motor symptoms and complications were not identified as predictors of caregiver burden. Associations between caregiver burden and non-motor symptoms of PD, such as depression and psychosis, cognitive impairment and behavioural problems, are well documented in the reviewed studies. Moreover, several studies report patient depression and behavioural problems as predictors of caregiver burden. In addition, comorbidity of depression, apathy, psychosis, dementia and impulse control disorders in patients correlate with significantly greater burden for caregivers, whereas the individual contribution of patient dementia on caregiver burden was inconclusive. Furthermore, when comparing the impact of patient motor and non-motor symptoms on caregiver burden, several studies found that patients' mental symptoms have a stronger impact on caregiver burden than motor symptoms or functional impairment. This finding differs from the review by Lau et al. [10], who revealed that patient motor symptoms and dependency in ADL were most strongly correlated with caregiver distress, while the weakest association was the patient's cognition. The different inclusion criteria applied in the review by Lau et $a l$. [10] and the present review, which resulted in an overlap of only 6 studies, might explain the divergent result. The correlation between burden, assessed by various caregiver burden instruments, and patient HRQoL measured by disease specific as well as generic instruments, is clear. The only included study that employed a QoL instrument that goes beyond a health status assessment did not identify a significant relationship between QoL and caregiver burden. As the authors suggest, this indicates the relevance of studying subjective QoL and self-assessed health status as separate concepts [66].

Despite the fact that many of the authors comment on cultural and ethnic family structures, as well as caring traditions that might influence caregiver burden in their sample [32] [34] [35] [38] [39] [51] [61] [63], there is no obvious evidence of variation in caregiver burden between studies representing European, North- and South American, as well as Asian cultures. The only international comparative study [54] observed an equal amount of 
total strain in Japanese and US caregivers despite the differences in demographics and social support, although the two groups differed significantly on several single strain items and the factors that contribute to caregiver strain. Contrary to the expectations due to different caring traditions, the included studies reveal little gender difference in caregiver burden. In contrast, in their meta-analysis of 164 studies of different caregiver samples, Pinquart and Sörensen [96] reported a small but statistically and practically significant gender difference in caregiver burden, with women reporting the highest burden. The influence of patient or caregiver age on reported caregiver burden was found in two studies comparing various caregiver age groups. However, when comparing the younger with the older group the two studies were contradictory in terms of which group was the most burdened. There is also conflicting evidence in the studies about whether caregiver spouses are more burdened than non-spouses, as spouses and non-spouses tend to differ with respect to burden domains, how they are affected and which factors contribute to caregiver burden. In addition, other aspects such as the emotional relationship might explain the inconsistent results. In a literature review carried out by Carbonneau et al. [97], the quality of the relationship was found to impact on caregiver stress. This is supported by a few of the reviewed studies, in which it is stated that caregivers' assessment of the quality of their relationship with the care recipient [25] [41] and mutuality in the relationship [25] [26] had a protective effect on caregiver burden.

\subsection{What Instruments and Which Analysis Methods Were Used?}

A number of instruments are available for measuring caregiver burden. Durme et al. [14] identified 55 scales (mainly generic) for assessing the negative impact of caregiving, 42 of which evaluate burden, strain or stress as the main dimension. There could be various reasons for choosing one instrument over another. In this review, the ZBI was the instrument used in most studies (11 studies). Durme et al. [14] rated the ZBI as the preferred caregiver burden instrument and good reliability has been reported in a PD setting [37]. According to Deeken et $a l$. [15] and Den Oudsten et al. [98], the choice of outcome instrument in research should be based on a clear understanding of the phenomenon under study. In the present review, 15 of the 31 studies presented a definition or conceptualization of caregiver burden, distress, strain or stress, while one study had an explicitly theoretical approach. The diversity of burden instruments, lack of a specific definition of burden and the absence of validity testing in a PD setting make it challenging to standardise tools for assessing caregiver burden in PD. Lack of conceptual consistency and standardization of burden measures leads to problems comparing the burden outcomes across instruments. This was illustrated in the study by Leroi et al. [49], who included two caregiver burden instruments. Significant differences were found between caregivers of PDD patients compared to those caring for non-PDD patients when assessed by the ZBI, but not by the NPI-CD. To achieve a more unequivocal picture reflecting the burden of PD caregivers, a smaller number of consistent instruments should be used when planning future studies. Recommendations should be made about the most appropriate caregiver burden instruments for a PD setting, as has been done for other factors associated with PD, including depression [99], fatigue [100], psychoses [101] and HRQoL [102].

With regard to the choice of caregiver burden instruments, a wide range of instruments were chosen in the selected studies to measure similar patient characteristics. For instance, five and seven different scales were used to measure patient functional ability and patient depression respectively. Practical or professional reasons within the research team might explain these choices. However, the variation in assessment tools impedes the opportunity to determine whether equal results indicate the same outcome and whether different results mirror real disparities. A lesser number of scales would make it possible to statistically integrate the results of the associations between caregiver burden and patient characteristics in a meta-analysis, which was not done in this review.

Comparison between studies also requires a clearly defined sampling unit in each study. Six of the 31 selected studies only included spouse or partner caregivers. However, in most studies the analyses are limited to the total group of caregivers. The absence of considerations about and stratification of subgroups in the analysis phase of caregiver studies has previously been criticized for limiting the understanding of caregiver burden [103]. This view is supported by the studies in the present review that provide separate analysis for different caregiver groups or control for variables that may influence the results. For instant, patient sex [25] [64] [65], comorbidity [36] [37] [49]-[51] and the patient-caregiver relationship [34] [65] were differently correlated with caregiver burden in distinct groups of caregivers. In addition, multivariate analysis provided further information about how caregiver age [26], presence of dementia in the patient [64], as well as the patient's depression and UPDRS mentation and motor scores [63] might make a different contribution to burden across caregiver groups. 
The various caregiver scales, number of subscales and the different scope of items used in the reported studies demonstrate the multidimensional nature of caregiver burden. However, several of the included studies treat burden as a one-dimensional variable and only present a sum score showing the overall burden without any information about sub-scores. For many years lack of such information has been criticized for not permitting a distinction to be made between various dimensions of burden [44], for masking variation in the correlates between different patient characteristics and the dimensions of strain [60], and for overlooking the relative contribution of specific domains of burden to the overall burden scores [104]. The few included studies that provide information about subscales partly address this criticism. An example is the comparative study of Japanese and American caregivers in which the CSI sum scores were the same, whereas single item scores differed significantly between the two caregiver groups [54]. Furthermore, the study by Kim et al. [32] demonstrates that several patient characteristics were differently associated with caregivers' subjective and objective burden scores. In addition, patient functional disability [28] [29], caregiver age [26] [32] and the spouses' relationship with the patient [29] have different associations within various subscales. Another aspect of the multifaceted character of caregiver burden is the assumption that it is influenced by many different factors. The majority of the selected studies considered this problem as the researchers performed a multivariate analysis. However, in contrast to the review by Greenwell et al. [18] who only included studies that identified predictive factors, the present study contains a correlation analysis to include studies that did not meet the criteria for a multiple regression analysis [105].

\subsection{Limitations}

This systematic review has several limitations. A meta-analysis was not possible due to the diversity of the instruments used in the various studies. In addition, only quantitative studies using a caregiver burden instrument as an outcome measure of caregiver stress and burden were included. Accordingly, studies employing other methods and instruments that could provide further knowledge about the subject were excluded. Finally, to fully understand the complexity of caring experiences and to plan effective interventions, caregiver-related variables as well as those that may be associated with positive outcomes for the caregiver are required. In addition, the risk of bias needs to be discussed with regard to how the systematic review was carried out. Two of the authors independently assessed the methodological quality. Differences in judgment were resolved by discussion between the authors, who agreed on the final version. However, it is important to acknowledge that this review represents the authors' understanding of the studies analysed. When conducting a review, researchers are in danger of making choices regarding the selection of studies and data extraction that expose the review to the risk of bias. However, we have strived to reduce the risk of bias by means of a comprehensive search in several electronic databases, formulating explicit inclusion and exclusion criteria for these lection of studies and by cooperation between authors in the data extraction.

\section{Conclusions and Implications}

Many patient characteristics are thoroughly documented as having an impact on caregiver burden in PD. Patient non-motor symptoms seem to have a stronger impact on caregiver burden than motor symptoms or functional impairment. Nevertheless, there is a need to fill a gap in the knowledge about how non-motor symptoms associated with PD such as patient anxiety, apathy, fatigue, sleep problems and the frequency of falls influence caregiver burden. Future research should also give priority to longitudinal studies in order to deepen the understanding of caregiver burden over time, as well as the expected needs in the caregiving situation. Furthermore, when planning studies on caregiver burden, a more uniform selection of burden instruments and scales to assess clinical characteristics would facilitate comparison among studies, thus deepening the knowledge of caregiver burden in PD.

In most of the included studies the analysis is restricted to the sum scores of the caregiver burden instruments. The majority of studies involved caregivers with different relationships to the care recipient, although relatively few studies contained a subgroup analysis of the caregiver respondents. Accordingly, there is a lack of knowledge about which areas cause the greatest burden to caregivers and whether some caregivers are more vulnerable and if so, for what reason. For clinical purposes, it would be appropriate to conduct subscale and subgroup analyses of caregivers' experiences in order to provide differentiated and targeted approaches to caregiver needs. This could facilitate healthcare professionals to plan appropriate intervention programmes that might reduce the 
burden on caregivers and prevent or postpone institutionalization.

\section{Acknowledgements}

This research was partly funded by the Centre for Women's, Family \& Child Health, Faculty of Health, Institute of Nursing Science, Buskerud and Vestfold University College, Kongsberg, Norway and the Centre for Movement Disorders, Stavanger University Hospital, Stavanger, Norway. The authors would like to thank the librarian Jannicke Rusnes Barnes, Stavanger University Hospital for her valuable contribution in the electronic search for papers. We would like to thank Monique Federsel for reviewing the English language.

\section{Competing Interest}

The author's declare that there are no conflicts of interest.

\section{Contributors}

The study was designed by I.L. I.L. coordinated the research. All authors participated in the data analysis. The report was written by I.L. E.S. supervised the study.

\section{References}

[1] Alves, G., Forsaa, E.B., Pedersen, K.F., et al. (2008) Epidemiology of Parkinson's Disease. Journal of Neurology, 255, 18-32. http://dx.doi.org/10.1007/s00415-008-5004-3

[2] Ahlskog, J.E. and Muenter, M.D. (2001) Frequency of Levodopa-Related Dyskinesias and Motor Fluctuations as Estimated from the Cumulative Literature. Movement Disorders, 16, 448-458. http://dx.doi.org/10.1002/mds.1090

[3] Obeso, J.A., Olanow, C.W. and Nutt, J.G. (2000) Levodopa Motor Complications in Parkinson's Disease. Trends in Neurosciences, 23, S2-S7. http://dx.doi.org/10.1016/S1471-1931(00)00031-8

[4] Witjas, T., Kaphan, E., Azulay, J.P., et al. (2002) Nonmotor Fluctuations in Parkinson's Disease: Frequent and Disabling. Neurology, 59, 408-413. http://dx.doi.org/10.1212/WNL.59.3.408

[5] Abendroth, M., Lutz, B.J. and Young, M.E. (2012) Family Caregivers' Decision Process to Institutionalize Persons with Parkinson's Disease: A Grounded Theory Study. The International Journal of Nursing Studies, 49, 445-454. http://dx.doi.org/10.1016/j.ijnurstu.2011.10.003

[6] McLennon, S.M., Habermann, B. and Davis, L.L. (2010) Deciding to Institutionalize: Why Do Family Members Cease Caregiving at Home? Journal of Neuroscience Nursing, 42, 95-103. http://dx.doi.org/10.1097/JNN.0b013e3181ce5c45

[7] Findley, L.J. (2007) The Economic Impact of Parkinson's Disease. Parkinsonism \& Related Disorders, 13, S8-S12. http://dx.doi.org/10.1016/j.parkreldis.2007.06.003

[8] Vossius, C., Nilsen, O.B. and Larsen, J.P. (2009) Parkinson's Disease and Nursing Home Placement: The Economic Impact of the Need for Care. European Journal of Neurology, 16, 194-200. http://dx.doi.org/10.1111/j.1468-1331.2008.02380.x

[9] Martinez-Martin, P., Arroyo, S., Rojo-Abuin, J.M., et al. (2008) Burden, Perceived Health Status, and Mood among Caregivers of Parkinson's Disease Patients. Movement Disorders, 23, 1673-1680. http://dx.doi.org/10.1002/mds.22106

[10] Lau, K.M. and Au, A. (2011) Correlates of Informal Caregiver Distress in Parkinson's Disease: A Meta-Analysis. Clinical Gerontologist, 34, 117-131. http://dx.doi.org/10.1080/07317115.2011.539521

[11] McRae, C., Sherry, P. and Roper, K. (1999) Stress and Family Functioning among Caregivers of Persons with Parkinson's Disease. Parkinsonism \& Related Disorders, 5, 69-75. http://dx.doi.org/10.1016/S1353-8020(99)00012-7

[12] Kelly, D.H., McGinley, J.L., Huxham, F.E., et al. (2012) Health-Related Quality of Life and Strain in Caregivers of Australians with Parkinson's Disease: An Observational Study. BMC Neurology, 12, 57. http://dx.doi.org/10.1186/1471-2377-12-57

[13] Cousins, R., Davies, A.D.M., Turnbull, C.J. and Playfer, J.R. (2002) Assessing Caregiving Distress: A Conceptual Analysis and a Brief Scale. British Journal of Clinical Psychology, 41, 387-403. http://dx.doi.org/10.1348/014466502760387506

[14] Van Durme, T., Macq, J., Jeanmart, C. and Gobert, M. (2012) Tools for Measuring the Impact of Informal Caregiving of the Elderly: A Literature Review. International Journal of Nursing Studies, 49, 490-504. http://dx.doi.org/10.1016/j.ijnurstu.2011.10.011

[15] Deeken, J.F., Taylor, K.L., Mangan, P., et al. (2003) Care for the Caregivers: A Review of Self-Report Instruments Developed to Measure the Burden, Needs, and Quality of Life of Informal Caregivers. Journal of Pain and Symptom 
Management, 26, 922-953. http://dx.doi.org/10.1016/S0885-3924(03)00327-0

[16] Peters, M. (2014) Quality of Life and Burden in Caregivers for Patients with PD. Focus on Parkinson's Disease, 24, 44-48.

[17] Martinez-Martin, P., Rodriguez-Blazquez, C. and Forjaz, M.J. (2012) Quality of Life and Burden in Caregivers for Patients with Parkinson's Disease: Concepts, Assessment and Related Factors. Expert Review of Pharmacoeconomics \& Outcomes Research, 12, 221-230. http://dx.doi.org/10.1586/erp.11.106

[18] Greenwell, K., Van Wersch, A. and Walker, R. (2013) Determinants of Psychosocial Impact of Being a Carer of People Living with Parkinson's Disease: A Systematic Review. Journal of Parkinson's Disease, 3, 173.

[19] Liberati, A., Altman, D.G., Tetzlaff, J., et al. (2009) The PRISMA Statement for Reporting Systematic Reviews and Meta-Analyses of Studies That Evaluate Healthcare Interventions: Explanation and Elaboration. BMJ, 339, b2700. http://dx.doi.org/10.1136/bmj.b2700

[20] Green, S.B. (1991) How Many Subjects Does It Take to Do a Regression Analysis. Multivariate Behavioral Research, 26, 499-510. http://dx.doi.org/10.1207/s15327906mbr2603_7

[21] Boland, A. and Dickson, R. (2014) Doing a Systematic Review: A Student's Guide. SAGE Publications Ltd., London.

[22] Berg, R.C. and Underland, V. (2013) Obstetric Consequences of Female Genital Mutilation/Cutting (FGM/C). A Systematic Review. Norwegian Knowledge Centre for the Health Services (NOCK), Oslo.

[23] Jack, K., McLean, S.M., Moffett, J.K. and Gardiner, E. (2010) Barriers to Treatment Adherence in Physiotherapy Outpatient Clinics: A Systematic Review. Manual Therapy, 15, 220-228. http://dx.doi.org/10.1016/j.math.2009.12.004

[24] Polit, D.F. and Beck, C.T. (2004) Nursing Research: Principles and Methods. 7th Edition, Lippincott Williams \& Wilkins, Philadelphia.

[25] Lyons, K.S., Stewart, B.J., Archbold, P.G. and Carter, J.H. (2009) Optimism, Pessimism, Mutuality, and Gender: Predicting 10-Year Role Strain in Parkinson's Disease Spouses. Gerontologist, 49, 378-387. http://dx.doi.org/10.1093/geront/gnp046

[26] Carter, J.H., Lyons, K.S., Stewart, B.J., et al. (2010) Does Age Make a Difference in Caregiver Strain? Comparison of Young versus Older Caregivers in Early-Stage Parkinson's Disease. Movement Disorders, 25, 724-730. http://dx.doi.org/10.1002/mds.22888

[27] Carter, J.H., Stewart, B.J., Archbold, P.G., et al. (1998) Living with a Person Who Has Parkinson's Disease: The Spouse's Perspective by Stage of Disease. Movement Disorders, 13, 20-28. http://dx.doi.org/10.1002/mds.870130108

[28] Carter, J.H., Stewart, B.J., Lyons, K.S. and Archbold, P.G. (2008) Do Motor and Nonmotor Symptoms in PD Patients Predict Caregiver Strain and Depression? Movement Disorders, 23, 1211-1216. http://dx.doi.org/10.1002/mds.21686

[29] Aarsland, D., Larsen, J.P., Karlsen, K., et al. (1999) Mental Symptoms in Parkinson's Disease Are Important Contributors to Caregiver Distress. International Journal of Geriatric Psychiatry, 14, 866-874. http://dx.doi.org/10.1002/(SICI)1099-1166(199910)14:10<866::AID-GPS38>3.0.CO;2-Z

[30] Thommessen, B., Aarsland, D., Braekhus, A., et al. (2002) The Psychosocial Burden on Spouses of the Elderly with Stroke, Dementia and Parkinson's Disease. International Journal of Geriatric Psychiatry, 17, 78-84. http://dx.doi.org/10.1002/gps.524

[31] Caap-Ahlgren, M. and Dehlin, O. (2002) Factors of Importance to the Caregiver Burden Experienced by Family Caregivers of Parkinson's Disease Patients. Aging Clinical and Experimental Research, 14, 371-377. http://dx.doi.org/10.1007/BF03324464

[32] Kim, K.S., Kim, B.J., Kim, K.H., et al. (2007) Subjective and Objective Caregiver Burden in Parkinson's Disease. Daehan Ganho Haghoeji, 37, 242-248.

[33] Leiknes, I., Tysnes, O.-B., Aarsland, D. and Larsen, J.P. (2010) Caregiver Distress Associated with Neuropsychiatric Problems in Patients with Early Parkinson's Disease: The Norwegian ParkWest Study. Acta Neurologica Scandinavica, 122, 418-424. http://dx.doi.org/10.1111/j.1600-0404.2010.01332.x

[34] Sarandol, A., et al. (2010) Behavioral Disturbances and Depression of Patients with Parkinson's Disease Have Significant Impact on Caregivers' Burden and Depression. Neurology Psychiatry and Brain Research, 16, 91-96.

[35] Agrawal, V., Goyal, V., Shukla, G. and Behari, M. (2012) Predictors of Caregivers' Burden of Parkinson's Disease in India: Experience of a Tertiary Care Centre in India. Journal of Parkinsonism \& Restless Legs, 2012, 59-65.

[36] Leroi, I., Harbishettar, V., Andrews, M., et al. (2012) Carer Burden in Apathy and Impulse Control Disorders in Parkinson's Disease. International Journal of Geriatric Psychiatry, 27, 160-166. http://dx.doi.org/10.1002/gps.2704

[37] Martinez-Martin, P., Forjaz, M.J., Frades-Payo, B., et al. (2007) Caregiver Burden in Parkinson's Disease. Movement Disorders, 22, 924-931. http://dx.doi.org/10.1002/mds.21355

[38] Ozdilek, B. and Gunal, D.I. (2012) Motor and Non-Motor Symptoms in Turkish Patients with Parkinson's Disease Affecting Family Caregiver Burden and Quality of Life. Journal of Neuropsychiatry and Clinical Neurosciences, 24, 478- 
483. http://dx.doi.org/10.1176/appi.neuropsych.11100315

[39] Razali, R., Ahmad, F., Rahman, F.N.A., et al. (2011) Burden of Care among Caregivers of Patients with Parkinson Disease: A Cross-Sectional Study. Clinical Neurology and Neurosurgery, 113, 639-643. http://dx.doi.org/10.1016/j.clineuro.2011.05.008

[40] Zarit, S.H., Todd, P.A. and Zarit, J.M. (1986) Subjective Burden of Husbands and Wives as Caregivers: A Longitudinal Study. Gerontologist, 26, 260-266. http://dx.doi.org/10.1093/geront/26.3.260

[41] Goldsworthy, B. and Knowles, S. (2008) Caregiving for Parkinson's Disease Patients: An Exploration of a Stress-Appraisal Model for Quality of Life and Burden. Journals of Gerontology Series B-Psychological Sciences and Social Sciences, 63, P372-P376. http://dx.doi.org/10.1093/geronb/63.6.P372

[42] Zarit, S.H., Reever, K.E. and Bach-Peterson, J. (1980) Relatives of the Impaired Elderly: Correlates of Feelings of Burden. Gerontologist, 20, 649-655. http://dx.doi.org/10.1093/geront/20.6.649

[43] Zarit, S.H., Orr, N.K. and Zarit, J.M. (1985) The Hidden Victim of Alzheimer's Disease: Families under Stress. New York University Press, New York.

[44] Novak, M. and Guest, C. (1989) Application of a Multidimensional Caregiver Burden Inventory. Gerontologist, 29, 798-803. http://dx.doi.org/10.1093/geront/29.6.798

[45] Greene, J.G., Smith, R., Gardiner, M. and Timbury, G.C. (1982) Measuring Behavioural Disturbance of Elderly Demented Patients in the Community and Its Effects on Relatives: A Factor Analytic Study. Age Ageing, 11, 121-126. http://dx.doi.org/10.1093/ageing/11.2.121

[46] Archbold, P.G., Stewart, B.J., Greenlick, M.R. and Harvath, T. (1990) Mutuality and Preparedness as Predictors of Caregiver Role Strain. Research in Nursing \& Health, 13, 375-384. http://dx.doi.org/10.1002/nur.4770130605

[47] Aarsland, D., Bronnick, K., Ehrt, U., et al. (2007) Neuropsychiatric Symptoms in Patients with Parkinson's Disease and Dementia: Frequency, Profile and Associated Caregiver Stress. Journal of Neurology, Neurosurgery \& Psychiatry, 78, 36-42. http://dx.doi.org/10.1136/jnnp.2005.083113

[48] Cummings, J.L., Mega, M., Gray, K., et al. (1994) The Neuropsychiatric Inventory: Comprehensive Assessment of Psychopathology in Dementia. Neurology, 44, 2308-2314. http://dx.doi.org/10.1212/WNL.44.12.2308

[49] Leroi, I., McDonald, K., Pantula, H. and Harbishettar, V. (2012) Cognitive Impairment in Parkinson Disease: Impact on Quality of Life, Disability, and Caregiver Burden. Journal of Geriatric Psychiatry and Neurology, 25, 208-214. http://dx.doi.org/10.1177/0891988712464823

[50] Marsh, L., Williams, J.R., Rocco, M., et al. (2004) Psychiatric Comorbidities in Patients with Parkinson Disease and Psychosis. Neurology, 63, 293-300. http://dx.doi.org/10.1212/01.WNL.0000129843.15756.A3

[51] Stella, F., Banzato, C.E., Quagliato, E.M., et al. (2009) Psychopathological Features in Patients with Parkinson's Disease and Related Caregivers’ Burden. International Journal of Geriatric Psychiatry, 24, 1158-1165. http://dx.doi.org/10.1002/gps. 2240

[52] Kaufer, D.I., Cummings, J.L., Christine, D., et al. (1998) Assessing the Impact of Neuropsychiatric Symptoms in Alzheimer's Disease: The Neuropsychiatric Inventory Caregiver Distress Scale. Journal of the American Geriatrics Society, 46, 210-215. http://dx.doi.org/10.1111/j.1532-5415.1998.tb02542.x

[53] Robinson, B.C. (1983) Validation of a Caregiver Strain Index. Journals of Gerontology, 38, 344-348. http://dx.doi.org/10.1093/geronj/38.3.344

[54] Tanji, H., Koyama, S., Wada, M., et al. (2013) Comparison of Caregiver Strain in Parkinson's Disease between Yamagata, Japan, and Maryland, The United States. Parkinsonism \& Related Disorders, 19, 628-633. http://dx.doi.org/10.1016/j.parkreldis.2013.02.014

[55] Thornton, M. and Travis, S.S. (2003) Analysis of the Reliability of the Modified Caregiver Strain Index. Journals of Gerontology Series B: Psychological Sciences and Social Sciences, 58, S127-S132. http://dx.doi.org/10.1093/geronb/58.2.S127

[56] Peters, M., Fitzpatrick, R., Doll, H., et al. (2011) Does Self-Reported Well-Being of Patients with Parkinson's Disease Influence Caregiver Strain and Quality of Life? Parkinsonism \& Related Disorders, 17, 348-352. http://dx.doi.org/10.1016/j.parkreldis.2011.02.009

[57] Gruetzner, H. (1988) Alzheimer's: A Caregiver's Guide and Sourcebook. John Wiley \& Sons, New York.

[58] Elmstahl, S., Ingvad, B. and Annerstedt, L. (1998) Family Caregiving in Dementia: Prediction of Caregiver Burden 12 Months after Relocation to Group-Living Care. International Psychogeriatrics, 10, 127-146. http://dx.doi.org/10.1017/S1041610298005249

[59] Montgomery, R.J.V., Gonyea, J.G. and Hooyman, N.R. (1985) Caregiving and the Experience of Subjective and Objective Burden. Family Relations, 34, 19-26. http://dx.doi.org/10.2307/583753

[60] Stull, D.E. (1996) The Multidimensional Caregiver Strain Index (MCSI): Its Measurement and Structure. Journal of Clinical Geropsychology, 2, 175-196. 
[61] Carod-Artal, F.J., Mesquita, H.M., Ziomkowski, S. and Martinez-Martin, P. (2013) Burden and Health-Related Quality of Life among Caregivers of Brazilian Parkinson's Disease Patients. Parkinsonism \& Related Disorders, 19, 943-948. http://dx.doi.org/10.1016/j.parkreldis.2013.06.005

[62] Schrag, A., Hovris, A., Morley, D., et al. (2006) Caregiver-Burden in Parkinson's Disease Is Closely Associated with Psychiatric Symptoms, Falls, and Disability. Parkinsonism \& Related Disorders, 12, 35-41. http://dx.doi.org/10.1016/j.parkreldis.2005.06.011

[63] Shin, H., Lee, J.Y., Youn, J., et al. (2012) Factors Contributing to Spousal and Offspring Caregiver Burden in Parkinson's Disease. Movement Disorders, 27, S311-S311.

[64] Calder, S.A., Ebmeier, K.P., Stewart, L., et al. (1991) The Prediction of Stress in Carers: The Role of Behaviour, Reported Self-Care and Dementia in Patients with Idiopathic Parkinson's Disease. International Journal of Geriatric Psychiatry, 6, 737-742. http://dx.doi.org/10.1002/gps.930061008

[65] Oguh, O., Kwasny, M., Carter, J., et al. (2013) Caregiver Strain in Parkinson's Disease: National Parkinson Foundation Quality Initiative Study. Parkinsonism \& Related Disorders, 19, 975-979. http://dx.doi.org/10.1016/j.parkreldis.2013.06.015

[66] Kudlicka, A., Clare, L. and Hindle, J.V. (2014) Quality of Life, Health Status and Caregiver Burden in Parkinson's Disease: Relationship to Executive Functioning. International Journal of Geriatric Psychiatry, 29, 68-76. http://dx.doi.org/10.1002/gps.3970

[67] Hoehn, M.M. and Yahr, M.D. (1967) Parkinsonism: Onset, Progression and Mortality. Neurology, 17, 427-442. http://dx.doi.org/10.1212/WNL.17.5.427

[68] Schrag, A., Jahanshahi, M. and Quinn, N. (2000) How Does Parkinson's Disease Affect Quality of Life? A Comparison with Quality of Life in the General Population. Movement Disorders, 15, 1112-1118. http://dx.doi.org/10.1002/1531-8257(200011)15:6<1112::AID-MDS1008>3.0.CO;2-A

[69] Fahn, S. and Elton, R.L. (1987) Unified Parkinson's Disease Rating Scale. In: Fahn, S., Marsden, C., Goldstein, M. and Calne, C., Eds., Recent Developments in Parkinson's Disease, Macmillan Healthcare Information, Florham Park, 153-163.

[70] Marinus, J., Visser, M., Stiggelbout, A.M., et al. (2004) A Short Scale for the Assessment of Motor Impairments and Disabilities in Parkinson's Disease: The SPES/SCOPA. Journal of Neurology, Neurosurgery, and Psychiatry, 75, 388395. http://dx.doi.org/10.1136/jnnp.2003.017509

[71] Schwab, R.S. and England, A.C. (1969) Projection Technique for Evaluating Surgery in Parkinson's Disease. In: Billingham, F.H. and Donaldson, M.C., Eds., Third Symposium on Parkinson's Disease, Churchill Livingstone, Edinburgh, 152-157.

[72] Mahoney, F.I. and Barthel, D.W. (1965) Functional Evaluation: The Barthel Index. Maryland State Medical Journal, 14, 61-65.

[73] Lawton, M.P. and Brody, E.M. (1969) Assessment of Older People: Self-Maintaining and Instrumental Activities of Daily Living. Gerontologist, 9, 179-186. http://dx.doi.org/10.1093/geront/9.3 Part 1.179

[74] Pickering, R.M., Grimbergen, Y.A., Rigney, U., et al. (2007) A Meta-Analysis of Six Prospective Studies of Falling in Parkinson's Disease. Movement Disorders, 22, 1892-1900. http://dx.doi.org/10.1002/mds.21598

[75] Beck, A.T. and Steer, R.A. (1984) Internal Consistencies of the Original and Revised Beck Depression Inventory. Journal of Clinical Psychology, 40, 1365-1367. http://dx.doi.org/10.1002/1097-4679(198411)40:6<1365::AID-JCLP2270400615>3.0.CO;2-D

[76] Derogatis, L.R. (1993) The Brief Symptom Inventory (BSI): Administration, Scoring and Procedures Manual. National Computer Systems, Minneapolis.

[77] Radloff, L. (1977) The CES-D Scale: A Self-Report Depression Scale for Research in the General Population. Applied Psychological Measurement, 1, 385-401. http://dx.doi.org/10.1177/014662167700100306

[78] Sheikh, J.I. and Yesavage, J.A. (1986) Geriatric Depression Scale (GDS): Recent Evidence and Development of a Shorter Version. In: Brink, T.L., Ed., Clinical Gerontology: A Guide to Assessment and Intervention, Haworth Press, Binghamton, 165-173.

[79] Hamilton, M. (1960) A Rating Scale for Depression. Journal of Neurology, Neurosurgery, and Psychiatry, $23,56-62$. http://dx.doi.org/10.1136/jnnp.23.1.56

[80] Zigmond, A.S. and Snaith, R.P. (1983) The Hospital Anxiety and Depression Scale. Acta Psychiatrica Scandinavica, 67, 361-370. http://dx.doi.org/10.1111/j.1600-0447.1983.tb09716.x

[81] Montgomery, S.A. and Asberg, M. (1979) A New Depression Scale Designed to Be Sensitive to Change. British Journal of Psychiatry, 134, 382-389. http://dx.doi.org/10.1192/bjp.134.4.382

[82] Lezak, M.D. (1995) Neuropsychological Assessment. 3rd Edition, Oxford University Press, New York.

[83] Muslimovic, D., Post, B., Speelman, J.D. and Schmand, B. (2005) Cognitive Profile of Patients with Newly Diagnosed 
Parkinson Disease. Neurology, 65, 1239-1245. http://dx.doi.org/10.1212/01.wnl.0000180516.69442.95

[84] Folstein, M.F., Folstein, S.E. and McHugh, P.R. (1975) "Mini-Mental State". A Practical Method for Grading the Cognitive State of Patients for the Clinician. Journal of Psychiatric Research, 12, 189-198. http://dx.doi.org/10.1016/0022-3956(75)90026-6

[85] Marinus, J., Visser, M., Verwey, N.A., et al. (2003) Assessment of Cognition in Parkinson's Disease. Neurology, 61, 1222-1228. http://dx.doi.org/10.1212/01.WNL.0000091864.39702.1C

[86] Friedberg, G., Zoldan, J., Weizman, A. and Melamed, E. (1998) Parkinson Psychosis Rating Scale: A Practical Instrument for Grading Psychosis in Parkinson's Disease. Clinical Neuropharmacology, 21, 280-284.

[87] Gilleard, C.J. and Pattie, A.H. (1977) The Stockton Geriatric Rating Scale: A Shortened Version with British Normative Data. British Journal of Psychiatry, 131, 90-94. http://dx.doi.org/10.1192/bjp.131.1.90

[88] Chappell, N.L. and Reid, R.C. (2002) Burden and Well-Being among Caregivers: Examining the Distinction. Gerontologist, 42, 772-780. http://dx.doi.org/10.1093/geront/42.6.772

[89] Roth, R.M., Isquith, P.K. and Gioia, G.A. (2005) BRIEF-A: Behavior Rating Inventory of Executive FunctionAdult Version. Psychological Assessment Resources, Lutz, FL.

[90] Reisberg, B., Ferris, S.H., Franssen, E., et al. (1989) Clinical Features of a Neuropathologically Verified Familial Alzheimer's Cohort with Onset in the Fourth Decade: Comparison with Senile Onset Alzheimer's Disease and Etiopathogenic Implications. Progress in Clinical and Biological Research, 317, 43-54.

[91] Chaudhuri, K.R., Yates, L. and Martinez-Martin, P. (2005) The Non-Motor Symptom Complex of Parkinson's Disease: A Comprehensive Assessment Is Essential. Current Neurology and Neuroscience Reports, 5, 275-283. http://dx.doi.org/10.1007/s11910-005-0072-6

[92] Peto, V., Jenkinson, C. and Fitzpatrick, R. (1998) PDQ-39: A Review of the Development, Validation and Application of a Parkinson's Disease Quality of Life Questionnaire and Its Associated Measures. Journal of Neurology, 245, S10S14. http://dx.doi.org/10.1007/p100007730

[93] The EuroQol Group (1990) EuroQol-A New Facility for the Measurement of Health-Related Quality of Life. Health Policy, 16, 199-208. http://dx.doi.org/10.1016/0168-8510(90)90421-9

[94] Ware Jr., J., et al. (2002) User's Manual for the SF-12v2® Health Survey 2002. Quality Metric Incorporated, Lincoln, RI.

[95] Henrich, G. and Herschbach, P. (2000) Questions on Life Satisfaction (FLZM) - A Short Questionnaire for Assessing Subjective Quality of Life. European Journal of Psychological Assessment, 16, 150-159. http://dx.doi.org/10.1027//1015-5759.16.3.150

[96] Pinquart, M. and Sorensen, S. (2006) Gender Differences in Caregiver Stressors, Social Resources, and Health: An Updated Meta-Analysis. The Journals of Gerontology Series B: Psychological Sciences and Social Sciences, 61, 33-45. http://dx.doi.org/10.1093/geronb/61.1.P33

[97] Carbonneau, H., Caron, C. and Desrosiers, J. (2010) Development of a Conceptual Framework of Positive Aspects of Caregiving in Dementia. Dementia, 9, 327-353. http://dx.doi.org/10.1177/1471301210375316

[98] Den Oudsten, B.L., Van Heck, G.L. and De Vries, J. (2007) Quality of Life and Related Concepts in Parkinson's Disease: A Systematic Review. Movement Disorders, 22, 1528-1537. http://dx.doi.org/10.1002/mds.21567

[99] Schrag, A., Barone, P., Brown, R.G., et al. (2007) Depression Rating Scales in Parkinson's Disease: Critique and Recommendations. Movement Disorders, 22, 1077-1092. http://dx.doi.org/10.1002/mds.21333

[100] Friedman, J.H., Alves, G., Hagell, P., et al. (2010) Fatigue Rating Scales Critique and Recommendations by the Movement Disorders Society Task Force on Rating Scales for Parkinson's Disease. Movement Disorders, 25, 805-822. http://dx.doi.org/10.1002/mds.22989

[101] Fernandez, H.H., Aarsland, D., Fénelon, G., et al. (2008) Scales to Assess Psychosis in Parkinson's Disease: Critique and Recommendations. Movement Disorders, 23, 484-500. http://dx.doi.org/10.1002/mds. 21875

[102] Martinez-Martin, P., Jeukens-Visser, M., Lyons, K.E., et al. (2011) Health-Related Quality-of-Life Scales in Parkinson's Disease: Critique and Recommendations. Movement Disorders, 26, 2371-2380. http://dx.doi.org/10.1002/mds.23834

[103] Bedard, M., Pedlar, D., Martin, N.J., et al. (2000) Burden in Caregivers of Cognitively Impaired Older Adults Living in the Community: Methodological Issues and Determinants. International Psychogeriatrics, 12, 307-332. http://dx.doi.org/10.1017/S1041610200006426

[104] Nolan, M.R., Grant, G. and Ellis, N.C. (1990) Stress Is in the Eye of the Beholder: Reconceptualizing the Measurement of Carer Burden. Journal of Advanced Nursing, 15, 544-555. http://dx.doi.org/10.1111/j.1365-2648.1990.tb01853.x

[105] Pallant, J. (2007) SPSS Survival Manual: A Step by Step Guide to Data Analysing Using SPSS for Windows. 3rd Edition, Open University Press, Maidenhead and McGraw-Hill, New York. 